\title{
FIRE EFFECTS ON WILDLIFE IN THE CENTRAL HARDWOODS AND APPALACHIAN REGIONS, USA
}

\author{
Craig A. Harper ${ }^{*}$, W. Mark Ford ${ }^{2}$, Marcus A. Lashley ${ }^{3}$, Christopher E. Moorman ${ }^{4}$, and \\ Michael C. Stambaugh 5 \\ ${ }^{1 *}$ Department of Forestry, Wildlife, and Fisheries, University of Tennessee, \\ 2431 Joe Johnson Drive, Knoxville, Tennessee 37996, USA \\ ${ }^{2}$ US Geological Survey, Virginia Cooperative Fish and Wildlife Research Unit, \\ 106 Cheatham Hall, Virginia Polytechnic Institute and State University, \\ Blacksburg, Virginia 24061, USA \\ ${ }^{3}$ Department of Wildlife, Fisheries, and Aquaculture, Mississippi State University, \\ Box 9690, Mississippi State, Mississippi 39762, USA \\ ${ }^{4}$ Department of Forestry and Environmental Resources, North Carolina State University, \\ Box 7646, Raleigh, North Carolina 27695, USA \\ ${ }^{5}$ Department of Forestry, University of Missouri, \\ 203C ABNR Building, Columbia, Missouri 65211, USA \\ *Corresponding author: Tel.: +001-865-974-7992; e-mail: charper@utk.edu

\section{ABSTRACT}

\section{RESUMEN}

Fire is being prescribed and used increasingly to promote ecosystem restoration (e.g., oak woodlands and savannas) and to manage wildlife habitat in the Central Hardwoods and Appalachian regions, USA. However, questions persist as to how fire affects hardwood forest communities and associated wildlife, and how fire should be used to achieve management goals. We provide an up-to-date review of fire effects on various wildlife species and their habitat in the Central Hardwoods and Appalachians. Documented direct effects (i.e., mortality) on wildlife are rare. Indirect effects (i.e., changes in habitat quality) are influenced greatly by light availability,
El fuego prescrito está siendo propuesto y utilizado cada vez más para promover la restauración de los ecosistemas (por ej. los arbustales de robles y sabanas) y para manejar el hábitat de la fauna silvestre en los Bosques Centrales de Latifoliadas y en los Apalaches en EEUU. Sin embargo, persiste el interrogante en como el fuego afecta a las comunidades del bosque de latifoliadas y su fauna asociada, y cómo el fuego debería ser utilizado para lograr objetivos de manejo. Nosotros realizamos una revisión actualizada de los efectos del fuego en varias especies de fauna silvestre y su hábitat en los Bosques Centrales de Latifoliadas y los Apalaches. La documentación sobre los efectos directos del fuego (por ej., mortalidad) en la fauna silvestre son raros. Los efectos indirectos (por ej., cambios en la calidad del hábitat) son influenciados grandemente por la disponibilidad de luz, y la frecuencia y la in- 
fire frequency, and fire intensity. Unless fire intensity is great enough to kill a portion of the overstory, burning in closed-canopy forests has provided little benefit for most wildlife species in the region because it doesn't result in enough sunlight penetration to elicit understory response. Canopy reduction through silvicultural treatment has enabled managers to use fire more effectively. Fire intensity must be kept low in hardwoods to limit damage to many species of overstory trees. However, wounding or killing trees with fire benefits many wildlife species by allowing increased sunlight to stimulate understory response, snag and subsequent cavity creation, and additions of large coarse woody debris. In general, a fire-return interval of $2 \mathrm{yr}$ to $7 \mathrm{yr}$ benefits a wide variety of wildlife species by providing a diverse structure in the understory; increasing browse, forage, and soft mast; and creating snags and cavities. Historically, dormant-season fire was most prevalent in these regions, and it still is when most prescribed fire is implemented in hardwood systems as burn-days are relatively few in the growing season of May through August because of shading from leaf cover and high fuel moisture. Late growing-season burning increases the window for burning, and better control on woody composition is possible. Early growing-season fire may pose increased risk for some species, especially herpetofauna recently emerged from winter hibernacula (April) or forest songbirds that nest in the understory (May to June). However, negative population-level effects are unlikely unless the tensidad del fuego. A menos que la intensidad del fuego sea lo suficientemente grande como para matar una porción del estrato superior, las quemas en bosques con el canopeo cerrado han aportado poco beneficio a la mayoría de las especies de fauna silvestre en la región, porque no permiten la penetración de suficiente de luz solar para obtener una respuesta en el sotobosque. La reducción del canopeo a través de tratamientos silviculturales ha permitido a los gestores utilizar el fuego en forma más efectiva. La intensidad del fuego debe ser mantenida baja en bosques de latifoliadas para limitar el daño a algunas especies arbóreas del estrato superior. Sin embargo, hiriendo o matando árboles mediante su quema puede beneficiar a muchas especies de la fauna silvestre, al permitir así la entrada de la luz solar para estimular la respuesta del sotobosque, la creación de árboles muertos en pie y la subsecuente formación de cavidades en ellos, y la adición de restos leñosos gruesos. En general, un intervalo de retorno del fuego de 2 años a 7 años beneficia a una amplia variedad de especies de la fauna silvestre, proporcionando una estructura diversa en el sotobosque, incrementando el ramoneo, el forraje, y los frutos carnosos, y creando troncos muertos en pié y cavidades en ellos. Históricamente, el fuego en la temporada de dormancia era más preponderante en estas regiones, y todavía lo es cuando la mayoría de los fuegos prescriptos se implementan en sistemas de latifoliadas, dado que los días de quema son relativamente pocos en la temporada de crecimiento de mayo hasta agosto debido a la sombra de la cobertura de hojas y el alto contenido de humedad de los combustibles. Las quemas durante la temporada tardía de crecimiento incrementan la ventana de prescripción, y es posible un mejor control en la composición de leñosas. Los fuegos al principio de la temporada de crecimiento pueden ocasionar mayores riesgos para algunas especies, especialmente para la herpetofauna recién emergida de la hibernación (abril) o a los pájaros cantores del bosque que anidan en el sotobosque (mayo a junio). Sin embargo, efectos negativos a nivel de población son im- 
burned area is relatively large and early growing-season fire is used continually. We did not find evidence that fire is leading to population declines for any species, including Endangered Species Act (ESA)-listed species (e.g., Indiana bat [Myotis sodalis Mill. Allen] or northern long-eared bat [M. septentrionalis Trouess.]). Instead, data indicate that fire can enhance habitat for bats by increasing suitability of foraging and day-roost sites. Similarly, concern over burning and displacement of woodland salamanders (Plethodontidae), another taxa of heightened conservation concern, is alleviated when fire is prescribed along ecologically appropriate aspect and slope gradients and not forced into mesic, high site index environments where salamanders are most common. Because topography across the Central Hardwoods and Appalachians is diverse, we contend that applying fire on positions best suited for burning is an effective approach to increase regional landscape heterogeneity and biological diversity. Herein, we offer prescriptive concepts for burning for various wildlife species and guilds in the Central Hardwoods and Appalachians. probables a menos que el área quemada sea relativamente grande y las quemas sean utilizadas en la temporada temprana de crecimiento en forma continua. Nosotros no hemos encontrado evidencias de que el fuego esté conduciendo a la declinación de la población de cualquiera de las especies, incluyendo las listadas en la Ley de Especies Amenazadas (ESA) (por ej., el murciélago de Indiana [Myotsis sodalis Mill. Allen] o el murciélago orejudo $[M$. septentrionalis Touess.]). En cambio, los datos indican que el fuego puede favorecer el hábitat de los murciélagos al aumentar la capacidad de alimentarse y los sitios de percheo diurnos. En forma similar, una preocupación sobre las quemas y el desplazamiento de la salamandra de los arbustales (Plethodontidae), otro de los taxones de alto interés de conservación, se alivia cuando el fuego se prescribe a lo largo de orientaciones y gradientes de pendiente apropiados ecológicamente y no forzados a ambientes mésicos, donde los índices de presencia en el ambiente son altos y las salamandras son más comunes. Debido a que la topografía a través de los Bosques Centrales de Latifoliadas y de los Apalaches es diversa, nosotros bregamos para que la aplicación de fuego en las posiciones más apropiadas sea un acercamiento efectivo para aumentar la heterogeneidad regional del paisaje y la diversidad biológica. Al respecto, nosotros ofrecemos conceptos de prescripción para las quemas de varias especies de la fauna silvestre y especies asociadas en los Bosques Centrales de Latifoliadas y los Apalaches.

Keywords: fire frequency, fire intensity, fire prescriptions, hardwoods, prescribed fire, season of burning, southern Appalachians, wildlife

Citation: Harper, C.A., W.M. Ford, M.A. Lashley, C.E. Moorman, and M.C. Stambaugh. 2016. Fire effects on wildlife in the Central Hardwoods and Appalachian regions, USA. Fire Ecology 12(2): 127-159. doi: 10.4996/fireecology.1202127

\section{INTRODUCTION}

Fire has increasingly been recommended and used over the past two decades to manage hardwood and mixed hardwood-pine (Pinus spp. L.) systems of the Central Hardwoods and Central and Southern Appalachian (hereafter Appalachian) regions, USA (Figure 1; Yaussy 2000, Brose et al. 2001, Brose et al. 2014). The primary reasons for use of fire in hard- 


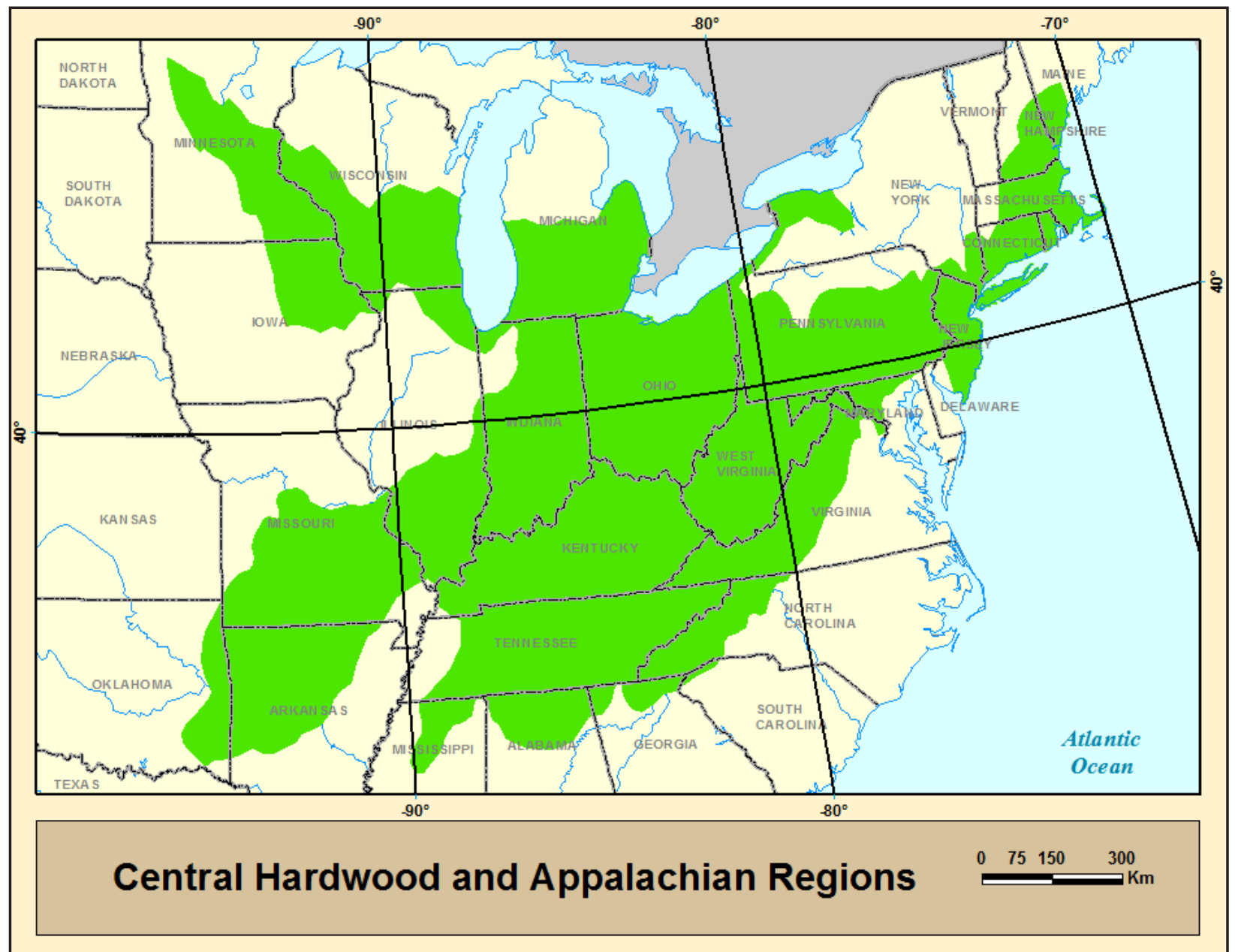

Figure 1. The Central Hardwoods and Appalachian forest types include a broad mixture of hardwood forests with a significant component of oak over diverse topography and physical settings that provides tremendous opportunity for managing multiple wildlife species and communities. Map adapted from Dyer (2006).

wood systems relate to the multiple benefits for ecosystem restoration (e.g., oak-pine woodlands or savanna), oak (Quercus spp. L.) regeneration, fuels reduction, and wildlife habitat management (McShea and Healy 2003, Burton et al. 2010, USDA Forest Service 2015). However, research investigating fire effects in eastern US deciduous forests is in its infancy compared to other regions and many questions remain unanswered (Stambaugh et al. 2015), particularly as related to wildlife. Because of the diverse requirements of the multiple taxa that occur in the region, fire effects and prescriptions vary greatly by location and with respect to different wildlife species
(Smith 2000), with no single prescription optimal for all wildlife species.

Fire is a critical tool for managing habitat for various wildlife species in Southern pine ecosystems (Johnson and Hale 2002, Van Lear et al. 2005, Masters 2006). Although the role of fire in restoration and maintenance of hardwood systems is less studied, empirical data regarding prevalence of fire and its use in hardwood systems shows that fire is important for maintaining and enhancing habitat for many wildlife species. Various fire prescriptions have been developed for pine ecosystems, such as frequent early growing-season fire in the longleaf pine (Pinus palustris Mill.) 
ecosystem (Frost 1998, Johnson and Hale 2002, Van Lear et al. 2005). However, the effects of fire on the vegetation and wildlife community often are considerably different in hardwood systems than in pine systems. In particular, the fuels and vegetation characteristics that facilitate the spread of fire, fire intensity, and the tolerance of overstory trees to fire intensity are quite disparate. Ongoing research and management continue to build understanding of how fire affects hardwood systems and associated wildlife. However, we believe sufficient information exists to guide management efforts, whether for a specific wildlife species, for a guild, or for ecosystem restoration. Our goal for this paper is to summarize current research of fire effects on wildlife in the Central Hardwoods and Appalachians, provide recommendations for fire prescriptions with regard to various wildlife species and species guilds given the latest information, and present suggestions for future research related to fire effects on wildlife.

\section{WHY ARE YOU BURNING?}

When land managers are asked why they burn, common answers are, "For wildlife," and, "Because burning is good." However, "wildlife" is an ambiguous term (Hunter and Schmiegelow 2011), and burning is not necessarily "good." Indeed, prescribed fire at some application and frequency may promote or enhance habitat for diverse taxa, such as reptiles (Russell et al. 1999, Greenberg 2000, Keyser et al. 2004), wild turkey (Meleagris gallopavo L.; McCord et al. 2014), and white-tailed deer (Odocoileus virginianus Zimmerman; Lashley et al. 2011), but its occurrence can be negative for these and other species, such as ovenbird (Seiurus aurocapilla L.; Rush et al. 2012) or eastern box turtle (Terrapene carolina L.; Howey and Roosenburg 2013), depending on when and how the burn is conducted. We contend that a major limitation in accomplishing land management goals related to fire use is failure to articulate precise management objectives or outcome assessment to determine their success. Often, it is unclear whether practitioners are burning for a focal species or group of species (e.g., shrubland songbirds), or whether it is for a target condition or ecosystem function (e.g., table mountain pine [Pinus pungens Lamb.] restoration in montane systems or an oak woodland). Confusion abounds as to whether burning should closely mimic what is regarded as the historic fire regime (Flatley et al. 2013, Hermann et al. 2015), or if fire should be used in a manner to create optimum habitat conditions for a particular wildlife species or group of species. There is a large dichotomy between managing an area so that it will support a certain species versus managing an area for maximum production of that species. This distinction is important, especially for public-lands managers when iconic game species or at-risk species occur, or when conditions desired for other stewardship considerations exist.

Understanding how different fire regimes affect various wildlife species as well as the vegetation community is critical (Rush et al. 2012). Commonly, when "wildlife" is the objective, multiple species with vastly different habitat requirements are listed as focal species, such as northern bobwhite (Colinus virginianus L.) and ruffed grouse (Bonasa umbellus L.). There is no published information distinguishing fire prescriptions for most wildlife species in the Central Hardwoods and Appalachians. Even for species that use similar vegetation types and successional stages, such as white-tailed deer and wild turkey, or northern bobwhite and eastern cottontail (Sylvilagus floridanus Allen), the fire prescription should differ (e.g., timing or frequency) if the objective is to optimize conditions for a focal species. Often, the fire prescription is not congruent with the biology and life history of the focal species. More consideration should be given to precise prescriptions that fit the biology of focal species as well as the ecology 
of an ecosystem. It should be recognized that, when multiple focal species exist, the appropriate fire regime for one species may conflict with another. In these situations, managers should first prioritize their objectives (decide which species is most important) and, if a conflict still exists, follow recommendations for fire frequency over those for fire intensity or seasonality.

\section{WHAT ARE FIRE EFFECTS ON WILDLIFE?}

Fire affects wildlife indirectly by impacting cover and food resources, and directly by causing injury or death (Smith 2000). The purpose of using fire is to set back or maintain a particular seral stage and influence plant composition, structure, and the subsequent successional trajectory. Therefore, by default, food and cover resources for various wildlife species are affected, positively for some species, neutrally for some species, and negatively for other species. Changes in food and cover also may influence core home range size (Rowan et al. 2005, Lashley et al. 2015), resource selection (Boyles and Aubrey 2006, Johnson et al. 2009, Kilburg et al. 2014), and movement of some species (Johnson et al. 2012). Indirect effects can be influenced greatly by area burned, pattern of burning, frequency and season of burning, and fire intensity (Lashley et al. 2015; Figure 2). Direct effects of fire on wildlife are much less common and poorly documented. In fact, observable direct mortality of most taxa by prescribed fire in hardwood systems is rare (Ford et al. 1999, Carter et al. 2002, Moseley et al. 2003, Howey and Roosenburg 2013). However, timing of burning and firing technique should be considered to reduce the likelihood of wildlife mortality or injury, as discussed below.

\section{FIRE AND SILVICULTURE}

Some discussion of fire and silviculture in hardwoods systems is warranted before de-

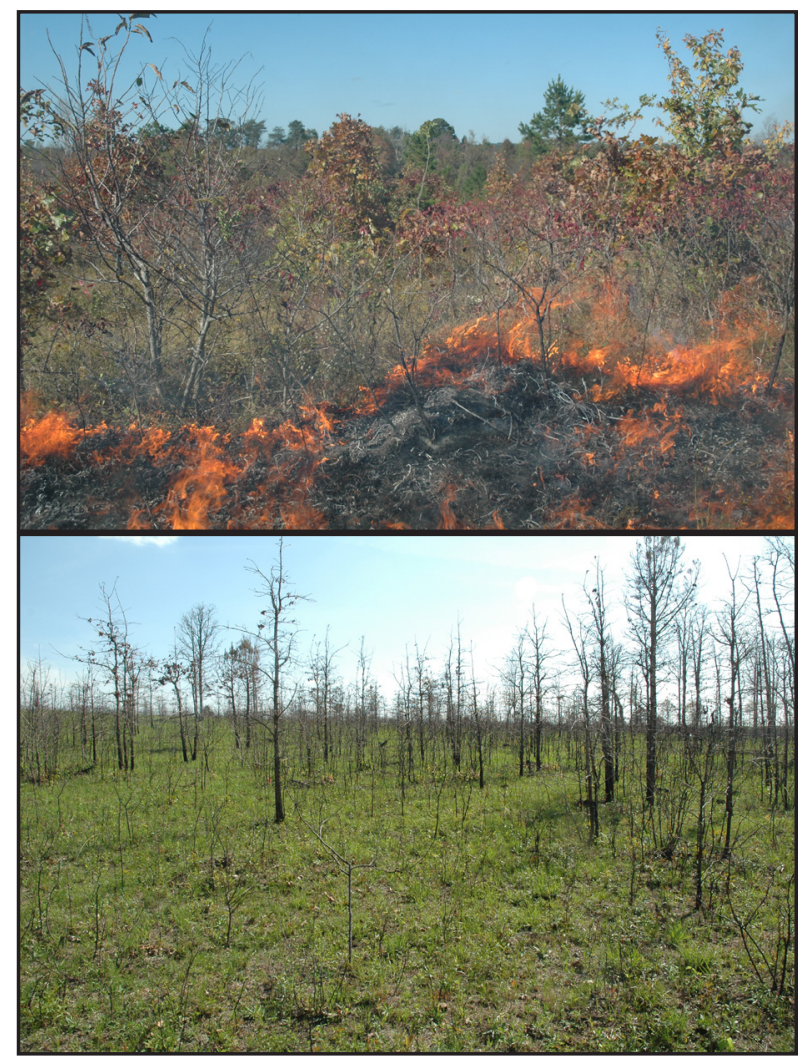

Figure 2. The biggest effects of fire on wildlife are indirect. Fire influences the structure and composition of vegetation, which changes availability of cover and food for wildlife. Indirect effects can influence presence, density, reproduction, survival, movements, and home range of wildlife in a particular area.

scribing fire effects and prescriptions for wildlife. Within a given size class, most hardwood species are more vulnerable to fire than yellow pines common in the southern US (e.g., longleaf, shortleaf [Pinus echinata Mill.], and loblolly [P. taeda L.] pines; Hare 1965, Harmon 1984). Therefore, if retention of a hardwood overstory is desired, relatively low-intensity fire must be used or injury and mortality of overstory trees are more likely (Wendell and Smith 1988, Marschall et al. 2014). However, without manipulation of the light environment, understory response following low-intensity fire can be negligible (Shaw et al. 2010, but see Schuler et al. 2013). Lashley et al. (2011) reported that forage availability for whitetailed deer was doubled by implementing 
low-intensity, early growing season fire under closed-canopy hardwoods, but coupling fire with canopy disturbance resulted in eight times as much deer forage as compared to unthinned and unburned areas. Through time, continued low-intensity fire will remove the midstory, but some level of canopy removal is necessary to allow sufficient sunlight (at least $20 \%$ full sunlight) to the forest floor to stimulate extensive groundcover (Royo et al. 2010, Schuler et al. 2010, McCord et al. 2014, Knapp et al. 2015).

Many silvicultural practices can be used with prescribed fire in hardwood systems to create, maintain, or enhance food and cover resources for wildlife. Regeneration harvests (e.g., shelterwood and group selection), various types of thinnings, and midstory removal via herbicide applications may be used in combination with fire to manage habitat for wildlife (Brose and Van Lear 1998, Johnson et al. 2009, Lashley et al. 2011, Bakermans et al. 2012, McCord et al. 2014, Kendrick et al. 2015, Silvis et al. 2016). The amount of canopy removal and resultant increased sunlight directly influences plant composition and structure, as well as habitat for different wildlife species. Increased canopy removal stimulates increased woody stem density, which may be suitable for species such as brown thrasher (Toxostoma rufum L.), chestnut-sided warbler (Dendroica pensylvanica L.), ruffed grouse, or black bear (Ursus americanus Pall.) (Brody and Stone 1987, van Manen and Pelton 1997, Whitaker et al. 2006, Matthews et al. 2010), but could be temporarily negative for others, such as Acadian flycatcher (Empidonax virescens Vieill.; Kendrick et al. 2015) and some terrestrial salamanders (Plethodontidae), which may be adversely affected by increased temperatures on the forest floor (Swift et al. 1993, Semlitsch et al. 2009, Ford et al. 2010, Matthews et al. 2010, O'Donnell et al. 2015).

Efforts to restore and create oak woodlands and savannas have increased in recent years, not only for habitat for various wildlife species (Brawn 2006, Barrioz et al. 2013, Ho- loubek and Jensen 2015), but also for ecosystem services (Pickens and Root 2008). Tree removal via mechanical disturbance or herbicide application often is used to expedite woodland and savanna restoration prior to use of prescribed fire for maintenance and to influence plant composition and structure. Without tree removal, creation of oak woodland or savanna may require many years, perhaps decades, of frequent and more intensive fire to achieve proper stand structure and understory composition (Knapp et al. 2015). Moderateto high-intensity fire would be required to sufficiently thin trees, which likely would damage residual boles. However, if wildlife is the primary objective, trees killed with moderate-intensity fire will benefit many wildlife species, retain biomass and nutrients on the site, and add to biological diversity (Hunter and Schmiegelow 2011). Tree removal allows use of less-intensive fire to influence groundcover composition and structure while minimizing damage to residual trees, thereby providing greater potential income if trees are later harvested (Kabrick et al. 2014, Dey and Schweitzer 2015).

\section{FIRE PRESCRIPTIONS AND EFFECTS ON WILDLIFE}

There are four primary factors regarding fire that affect wildlife directly and indirectly: 1) fire frequency, 2) fire intensity, 3) season (or timing) of burning, and 4) burn area and pattern of burning. We contend that fire effects on wildlife cannot be separated from fire effects on the vegetation community. Thus, both must be considered and understood before fire prescriptions can be recommended.

\section{Fire Frequency and Intensity}

Fire frequency is generally regarded as the most influential factor related to fire effects at local and landscape scales (Frost 1998, Nowacki and Abrams 2008). However, effects of fire frequency are so closely related to fire 
intensity that it is difficult to discuss one without considering the other. For example, low-intensity fire implemented frequently in a mature hardwood forest may have less of an effect on the vegetation and wildlife community than less-frequent high-intensity fire that kills overstory trees. Nonetheless, within a given range of intensity, fire frequency is a requisite consideration for maintaining an early seral stage in the eastern US where precipitation exceeds $75 \mathrm{~cm} \mathrm{yr}^{-1}$. This is a critical factor for wildlife species that require early successional communities (Harper 2007, Gruchy and Harper 2014).

Low-intensity fire under closed-canopy conditions tends to have no or only transitory effects on wildlife, including terrestrial salamanders (Ford et al. 1999, Greenberg and Waldrop 2008, Matthews et al. 2010, Raybuck et al. 2015). If fire intensity is great enough to kill midstory stems, understory response will increase slowly over time with repeated burning as scattered overstory trees eventually die. However, after 60 years of annual burning with low-intensity fire in an oak-hickory (-Carya spp. Nutt.) forest in Missouri, USA, percent coverage of understory vegetation still did not exceed 40\% (Knapp et al. 2015).

Silvicultural treatment can be used to increase light penetration and increase the influence of low-intensity fire on vegetation composition and structure. McCord et al. (2014) reported that low-intensity fire alone in Appalachian mixed hardwoods did not impact overstory basal area over a nine-year span with four fires. However, following improvement cutting or shelterwood harvest that allowed at least $20 \%$ to $30 \%$ sunlight into the stand, a fire-return interval within $6 \mathrm{yr}$ to $7 \mathrm{yr}$ maintained forest understory structure suitable for various forest birds, such as hooded warbler (Wilsonia citrina Bodd.), Kentucky warbler (Oporornis formosus Wilson), and worm-eating warbler (Helmitheros vermivorum Gmelin), that require a relatively dense understory of woody sprouts for nesting and foraging (Greenberg et al. 2007, Bakermans et al.
2012, McCord et al. 2014). Use of burned area by songbirds that require leaf litter (e.g., worm-eating warbler, black-and-white warbler [Mniotilta varia L.], and ovenbird), as well as terrestrial salamanders and some shrew (Soricidae) species, may be delayed for at least one growing season after burning until sufficient leaf litter accumulates and vegetation regrowth occurs (Artman et al. 2001, Greenberg et al. 2007, Matthews et al. 2009, Ford et al. 2010). A $3 \mathrm{yr}$ to $5 \mathrm{yr}$ fire-return interval was recommended to maintain structure suitable for nesting and brood-rearing wild turkey (McCord et al. 2014), as well as forage and soft mast for white-tailed deer following an improvement cut (Lashley et al. 2011). In old-field communities succeeding into dense, young trees, a 4 yr to $6 \mathrm{yr}$ fire-return is necessary to maintain habitat for shrubland birds (e.g., yellow-breasted chat [Icteria virens L.], blue-winged warbler [Vermivora pinus L.], and white-eyed vireo [Vireo griseus Bodd.]), whereas a 2 yr to 4 yr fire-return interval generally is needed in such environments to maintain structure required for species such as indigo bunting (Passerina cyanea L.), field sparrow (Spizella pusilla Wilson), northern bobwhite, loggerhead shrike (Lanius ludovicianus L.), and eastern cottontail (Wilson et al. 1995, Hunter et al. 2001; Figure 3). Moderate-intensity fire will injure or kill overstory hardwood trees, depending on the size and species. However, injury and mortality of trees benefits many wildlife species. Additional sunlight from canopy reduction stimulates understory growth and benefits shrub-nesting birds (Greenberg et al. 2007, 2013). Furthermore, injured and dead trees are used by many species, especially woodpeckers (Picidae), followed by secondary cavity users, including birds, bats, and tree squirrels (Greenberg et al. 2007, Hunter and Schmiegelow 2011, Greenberg et al. 2013). Trees injured by fire often are invaded by fungi, which may cause heart rot (Silvis et al. $2015 b$ ). Trees that die from the inside out, as opposed to from the outside in (e.g., when a tree is killed via girdling and herbicide injec- 


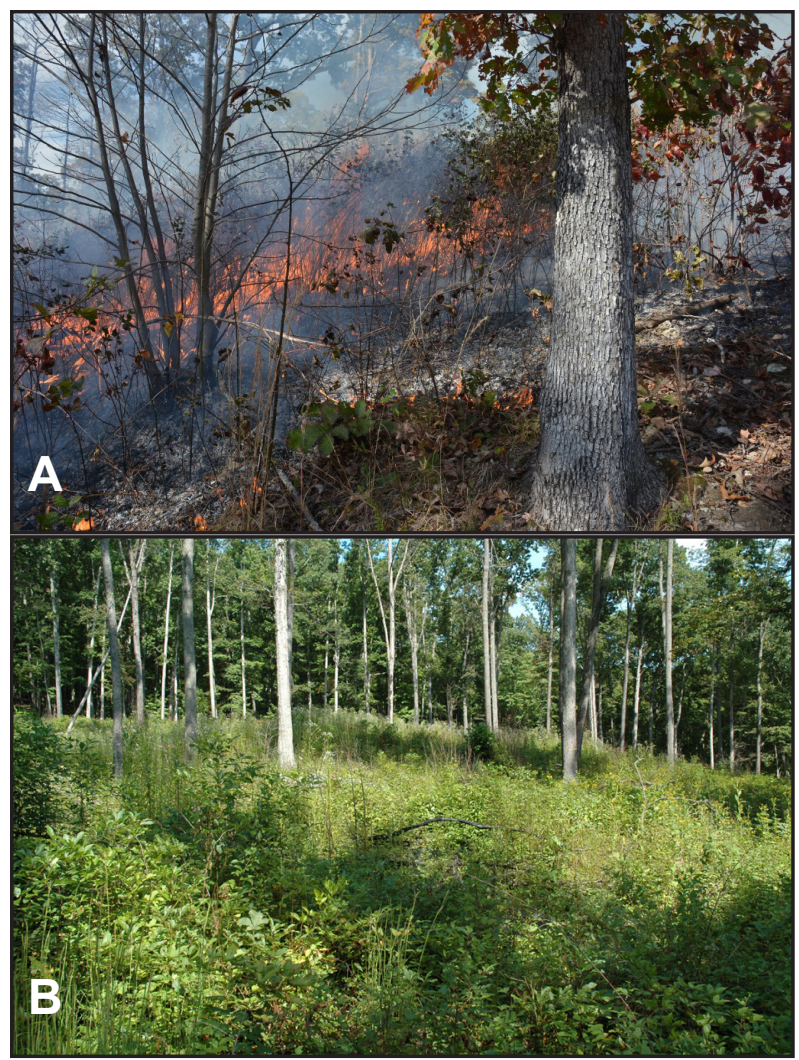

Figure 3. Silvicultural treatment, such as twoaged shelterwood in this mixed oak stand in the Ridge and Valley physiographic province of eastern Tennessee, USA, allows sunlight to enter the stand and stimulate groundcover response. Frequent, low-intensity prescribed fire (A, in October) is required to keep the understory from developing into a midstory and maintain the desired structure for various wildlife species (B, in September following fire). tion), have softer interiors favored by cavity excavators and typically persist longer on the landscape (Hunter and Schmiegelow 2011). Following moderate-intensity fire, low-intensity fire can be used within a 6 yr to 7 yr fire-return interval to maintain a woodland structure that is necessary for several species of birds (e.g., great-crested flycatcher [Myiarchus crinitus L.], summer tanager [Piranga rubra L.], eastern wood-pewee [Contopus virens L.], and red-headed woodpecker [Melanerpes erythrocephalus L.]). Several bat species (e.g., the endangered Indiana bat, eastern red bat [Lasiurus borealis Müller], and evening bat [Nycticus humeralis Rafinesque]) also benefit from canopy gaps and decreased structural clutter, which allows for greater foraging efficiency (Ford et al. 2006, Dickinson et al. 2009, Greenberg et al. 2013, Amelon et al. 2014, Starbuck et al. 2015).

Dead and dying trees are used by many species, including many rare, threatened, or endangered species. For example, Indiana bat and the newly listed (threatened) northern long-eared bat often day-roost during the summer maternity season under exfoliating bark and in cavities, respectively, of snags or trees in decline (Johnson et al. 2009, 2010; Silvis et al. 2015a). Data indicate that low-intensity fire can be used to maintain woodland structure without reducing available snags for these animals (Ford et al. 2015; Table 1). Further-

Table 1. Snag ( $>25 \mathrm{~cm}$ dbh) retention (per ha) following silvicultural treatment from 2001 to 2011 in the Chuck Swan State Forest, Union County, Tennessee, USA. (Data from study described in McCord et al. 2014.)

\begin{tabular}{lccc}
\hline & $\begin{array}{c}\mathbf{2 0 0 1} \\
\left(\text { density ha }^{-1}\right)\end{array}$ & $\begin{array}{c}\mathbf{2 0 0 8} \\
\left.\text { (density ha }^{-1}\right)\end{array}$ & $\begin{array}{c}\mathbf{2 0 1 1} \\
\left.\text { (density ha }^{-1}\right)\end{array}$ \\
\hline Control & 29.7 & 8.4 & 18.6 \\
Fire only $^{1}$ & 32.9 & 15.1 & 16.6 \\
Improvement cut $^{\text {Improvement cut with fire }}{ }^{1}$ & 57.7 & 40.4 & 18.6 \\
\hline
\end{tabular}

${ }^{1}$ Low-intensity early growing-season prescribed fire was implemented in "fire only" and "improvement cut with fire" treatments in 2001, 2005, 2007, and 2009. "Improvement cut" treatment killed trees deemed undesirable for wildlife and allowed approximately $30 \%$ sunlight into those stands. 
more, low-intensity fire is easily implemented when the duff layer is still relatively moist. Under such conditions, large down woody debris is not consumed, which is a critical consideration for terrestrial salamanders, reptiles, and shrews (Ford et al. 1999, 2010).

If tree density is reduced and the intention is to maintain woodland or savanna structure, more frequent fire is necessary (Peterson and Reich 2001, Barrioz et al. 2013), similar to the $1 \mathrm{yr}$ to $3 \mathrm{yr}$ fire-return interval necessary to maintain early successional communities and prevent young trees from dominating the site (Gruchy et al. 2009). However, frequent fire can have negative indirect effects on certain wildlife, such as suppression of soft mast production in the understory (Lashley et al. 2015b). Low- to moderate-intensity fire may be used in woodlands or savannas to influence plant composition without killing overstory trees. Moderate-intensity fire may be needed to help set back prolific hardwood sprouting after tree removal, especially if stems are larger than $8 \mathrm{~cm} \mathrm{dbh}$. However, practitioners must use the proper firing technique (e.g., backing fire, flanking fire, or strip-heading fire) to avoid injuring or killing overstory trees, and season of burning should be considered.

\section{Season (or Timing) of Burning}

Season of burning has implications for both wildlife and plant communities, and there may be less understanding of this factor than any other. Knapp et al. (2009) provided an excellent review of the literature pertaining to season of burning across broad regions of the US. However, relatively little data exist with regard to the effects of fire seasonality on wildlife and vegetation in the Central Hardwoods and Appalachians. Vegetation response to season of burning must be considered because of its explicit indirect effects on wildlife.

Effects on vegetation. Studies conducted in pine systems of the American South indicate that growing-season fire provides better control of encroaching hardwoods than dormant-season fire (Waldrop et al. 1992, Glitzenstein et al. 1995b, Drewa et al. 2002, Robertson and Hmielowski 2014, Hermann et al. 2015). As a result, growing-season fire is promoted widely, especially in the longleaf pine ecosystem, because it enhances habitat for the red-cockaded woodpecker (Picoides borealis Vieill.) and other wildlife, more closely mimics the historical fire regime that resulted from lightning ignition, and provides additional opportunity for burning days to accomplish desired stewardship management goals (Cox and Widener 2008). Timing of the growing-season fires in these studies varied, but most were conducted in May and June. It is important to remember, when considering vegetation effects and season of burning, that bud break in the Deep South occurs three to eight weeks earlier than in various areas of the more northerly Central Hardwoods and Appalachians. Therefore, with regard to plant phenology, burning during June in north Florida may be analogous to burning during July or August in the mountains of North Carolina or West Virginia.

Confusion exists as many managers erroneously equate woody stem "control" with elimination. Burning during the early portion of the growing season usually only top-kills young trees and shrubs, similar to dormant-season burning (McCord et al. 2014, Glitzenstein et al. 2015). Density of sprouts often increases following dormant-season fire, whereas woody stem density may increase less or remain unchanged following early growing-season fire (Robertson and Hmielowski 2014, Sparks et al. 1999, Drewa et al. 2002). Burning during the early growing season (April and early May) on a 2 yr fire-return interval for $9 \mathrm{yr}$ did not reduce woody stem density or coverage in the understory of Appalachian mixed upland hardwoods (McCord et al. 2014). Trees and shrubs were top-killed, but continued to resprout and dominate understory plant composition. Several studies have noted 
or speculated that it may require $\geq 10 \mathrm{yr}$ of frequent burning to realize an effect of seasonal burning on woody plant composition (Waldrop et al. 1992, Drewa et al. 2002, Robertson and Hmielowski 2014, Glitzenstein et al. 2015; Figure 4).

Limited data suggest that burning later in the growing season may reduce woody stem density more completely than burning during the dormant or early growing season. Lewis et al. (1964) reported that March burning in the Ozark Mountains increased hardwood sprouts, whereas burning in April, June, and August decreased hardwood sprouts, with slightly bet-

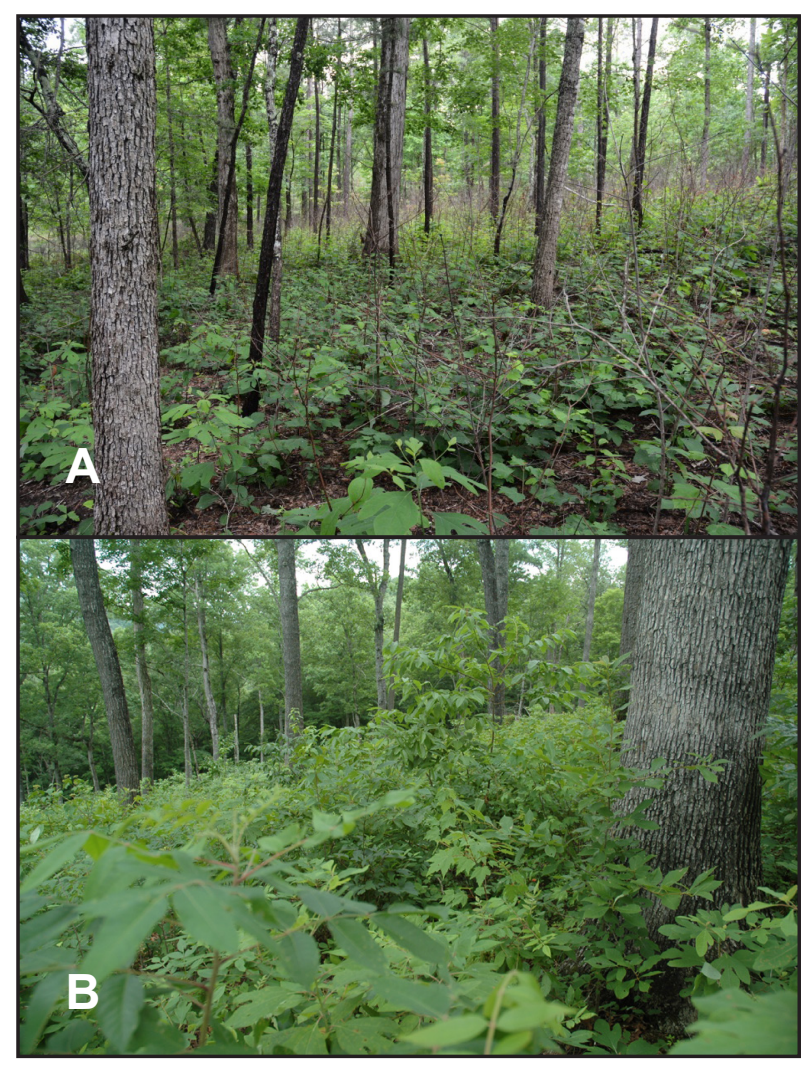

Figure 4. Early growing-season fire in mixed oak stands with a broken canopy will top-kill small woody stems, but the stems sprout back quickly, resulting in little compositional change in the understory (A; the growing season following second fire). However, for forest songbirds that nest and forage in a well-developed understory, as well as wild turkey and white-tailed deer, this type of structure provides good cover (B; second growing season following fourth fire). ter control in June and August than in April. In the upper Gulf Coastal Plain, Gruchy et al. (2009) reported that burning in September reduced encroachment of red maple (Acer rubrum L.), green ash (Fraxinus pennsylvanica Marsh.), and sweetgum (Liquidambar styraciflua L.) in an old-field community just as well as did applications of imazapyr and triclopyr, and much better than burning in March. However, different species are more resilient to burning and continue to resprout better than others, and at least some woody sprouting will occur regardless of burn timing. Sparks et al. (1999) reported that density of woody stems $<1 \mathrm{~m}$ tall was similar $3 \mathrm{yr}$ and $4 \mathrm{yr}$ after a single dormant- or late growing-season fire in shortleaf pine-hardwood stands managed for red-cockaded woodpecker in the Ouachita Mountains. Dormant-season fire controlled larger woody stems ( $>3 \mathrm{~m}$ tall) better than late growing-season fire, but that was because the late growing-season fire was not nearly as intense as the dormant-season fire and left unburned patches (Sparks et al. 1999). Small stems are easily top-killed with low-intensity fire as long as the cambium tissue is heated to $60^{\circ} \mathrm{C}$ to $70^{\circ} \mathrm{C}\left(140^{\circ} \mathrm{F}\right.$ to $\left.160^{\circ} \mathrm{F}\right)$ for a few minutes (Wright and Bailey 1982). Drewa et al. (2002) documented that burn timing, not intensity, was more influential on woody sprout regrowth as long as the fire was hot enough to kill the cambium. Continued burning is necessary to reduce woody stem density. However, it is possible that the fire-return interval may not have to be as frequent to control woody stem density when using late growing-season fire as compared to dormant- or early growing-season fire, within a similar range of fire intensity.

It has been speculated that continued frequent burning may deplete carbohydrate reserves and eventually render a plant unable to continue resprouting (Drewa et al. 2002, Robertson and Hmielowski 2014). Carbohydrate reserves of most woody plants typically decline with spring growth to a minimum in early summer, then build up again through the 
growing season (Wenger 1953, Landhausser and Lieffers 2002). Concentrations of starches in root systems decline after burning during the growing season as plants use reserves to regrow. Bowen and Pate (1993) reported that Australian shrubs required six months longer to restore starches depleted following summer burning (24 months) than spring burning (18 months). It is clear that frequent fire is necessary to deplete carbohydrate reserves as they are restored in many species relatively quickly (Waldrop et al. 1992, Schutz et al. 2009). However, the relationship between fire frequency, timing, and carbohydrate reserves on hardwood resprouting and the resulting plant community in the Central Hardwoods and Appalachian regions has not been investigated and is not well understood (Figure 5).

Timing of burning also may affect coverage and composition of herbaceous plants. Change in plant community composition is an important consideration for wildlife when determining fire prescriptions. There is little information available from the Central Hardwoods and Appalachian regions with regard to herbaceous response to seasonality of fire. Sparks et al. (1998) reported relatively little difference in herbaceous response between

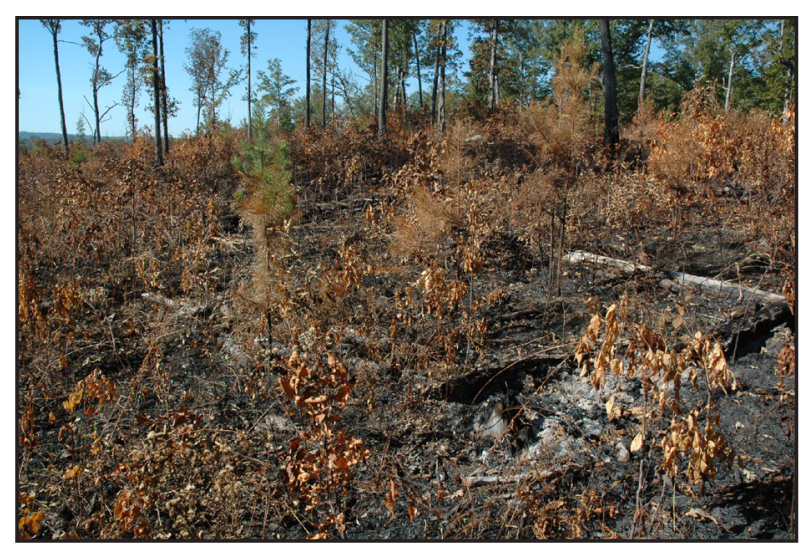

Figure 5. Fire intensity does not have to be great to top-kill small trees. These small trees were topkilled by a low-intensity prescribed fire in early October on the Cumberland Plateau in Tennessee in an effort to encourage more herbaceous groundcover in a developing oak savanna. late dormant-season and late growing-season fire when burning in open shortleaf pine stands in the Ouachita Mountains. Gruchy et al. (2009) reported that coverage of native legumes in an old-field community in the upper Gulf Coastal Plain increased from less than $10 \%$ in control to $25 \%$ after burning in March, and to $55 \%$ after burning in September. Lewis et al. (1964) reported greater forb production following burns in August than following burns in March or June in the Ozarks. Howe (2011) reported greater forb richness following burning in July than in May in the Great Lake states. Growing-season fire likely promotes increased coverage of herbaceous species as a result of reduced competition with woody species (Knapp et al. 2009). Burning during the dormant season tends to increase coverage of native warm-season $\left(\mathrm{C}_{4}\right)$ grasses, but no season of burning has reduced coverage of these grasses (Lewis et al. 1964, Holcomb et al. 2014). Burning different areas of a property during the late growing season as well as at other times of the year not only provides increased heterogeneity of cover, but also expands periods of high-quality forages for species such as white-tailed deer and elk (Cervus canadensis L.; Cook et al. 2013, Towne and Craine 2014, Lashley et al. 2015b).

Dendrochronological evidence indicates that dormant-season fire was much more frequent than growing-season fire historically in the Central Hardwoods and Appalachians, suggesting that native Americans were equally as responsible as lightning for spread of fire in this region, if not more so (Shumway et al. 2001, Flatley et al. 2013). The majority of lightning-caused fires in the region occurred from April through August (Ruffner and Abrams 1998, Cohen et al. 2007), but fires later in the growing season (August to October) may lead to increased fire spread because of drier conditions (Peterson and Drewa 2006). Fire prescriptions in hardwood systems of the Central Hardwoods and Appalachians largely have involved dormant-season fire (Van Lear 
and Waldrop 1989, Wade et al. 2000, Brose et al. 2001). Burning during the growing season is much more difficult in hardwood systems than in pine systems because of the shade effect and increased litter moisture in hardwoods, and the abundance and flammability of hardwood leaf litter is less than pine leaf litter (Varner et al. 2015). Often, burning May through mid-August is not possible in hardwood stands with considerable canopy coverage (Figure 6) except during exceptionally dry summers and, during those periods, it is common for state forestry agencies to implement burn bans. For much of the region, burning during the late growing season (August through October) historically occurred during extended dry periods when lower precipitation and less humidity resulted in drier fuels (Knapp et al. 2009). Following canopy-reduction treatment that allows additional sunlight into the stand, drying is expedited, better facilitating burning during these months. In open areas (e.g., old fields, forest openings, and savannas), conditions may allow burning during any month of the summer. Increased moisture and decreased flammability of fuels in hardwood systems during the growing season leads to relatively less-intensive fires than during the dormant season, which differs from pine systems in which increased fine fuels and sunlight

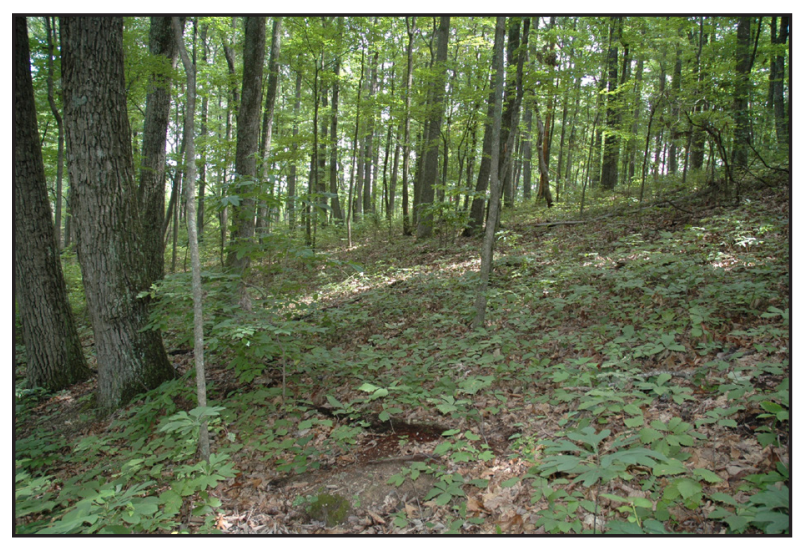

Figure 6. Burning hardwood stands in the Central Hardwoods and Appalachians from May to August is usually difficult because of shade effect and moisture retained in the leaf litter. may allow intensive fires any month during the growing season (Glitzenstein et al. 1995a).

Considerations for wildlife. Season of burning (along with fire intensity and firing technique) can influence the risk of direct mortality of wildlife. Animals are most vulnerable to mortality or injury from fire during nesting, brood-rearing, or fawning seasons, and soon after emerging from hibernacula (i.e., some herpetofauna). For most species, relatively few individuals in a population are affected by any given burn unless the area burned is relatively large and intense (Brennan et al. 1998). However, for a few species (e.g., timber rattlesnake [Crotalus horridus L.] soon after emergence from hibernacula, and eastern box turtle), a significant portion of the local population can be affected by a single fire (Beaupre and Douglas 2012, Howey and Roosenburg 2013). Data from the longleaf pine ecosystem have indicated that habitat improvement using fire can offset population losses or declines by improving habitat conditions in subsequent years (Engstrom et al. 2005, Cox and Widener 2008), especially for various birds, such as red-cockaded woodpecker (Walters 1997), Henslow's sparrow (Ammodramus henslowii Audubon; Thatcher et al. 2006), and Bachman's sparrow (Aimophila aestivalis Lich.; Tucker et al. 2004, Cox and Jones 2007).

Research on wildlife population response and season of fire in the Central Hardwoods and Appalachians also is limited. Concern has been expressed over potential effects of growing-season fire on herpetofauna (Russell et al. 1999, Renken 2006). Beaupre and Douglas (2012) reported that a local population of timber rattlesnakes declined dramatically following an early growing-season fire (April) that occurred soon after the snakes emerged from a den complex. The subpopulation slowly recovered over the following 11 years. It was assumed that the animals were destroyed by the fire, but studies that measure survival, not just occupancy, are needed to quantify direct 
effects. Mortality by fire should not be assumed just because surveys suggest fewer animals are present following fire. At another site, Beaupre and Douglas (2012) documented that dormant-season burning (March) and stand thinning led to increased prey and enhanced growth and body condition of timber rattlesnakes. Burning during the dormant season has had no overall negative effect on herpetofauna (Ford et al. 1999, Floyd et al. 2002, Keyser et al. 2004, Greenberg and Waldrop 2008, Raybuck et al. 2015). Moreover, American toad (Anaxyrus americanus Holbrook; Kirkland et al. 1996) and lizards (i.e., eastern fence lizard [Sceloporus undulates Bosc. Daudin], ground skink [Scincella lateralis J.], and southeastern five-lined skink [Eumeces inexpectatus Taylor]) increased in relative abundance on burned sites (Keyser et al. 2004, Greenberg and Waldrop 2008, Matthews et al. 2010). Dormant-season fire (December) led to decreased surface activity of southern redbacked salamanders (Plethodon serratus Grob.) for one growing season following burning in mixed oak-hickory forest, but rebounded by the second growing season (O'Donnell et al. 2015). Even for cryptic species (e.g., Ambystomatid salamanders), their life history traits suggest that direct effects are not likely given their nocturnal movements from winter hibernacula to breeding ponds during periods of wet weather in February and March (Briggler 2014).

Concern also has been expressed over possible effects of growing-season fire on bats, especially the Indiana bat. However, Dickinson (2010) reported that, according to standard toxicology models, carbon dioxide levels would have no deleterious effect on bats unless they were directly above the fireline of a very intense fire. A larger concern emanates from heat effects. However, models suggest that heat would not be a factor unless flame lengths exceeded $9 \mathrm{~m}$. Therefore, low- to moderate-intensity fire should have no direct effect on Indiana bats, the species of most con- cern relative to burning in the eastern US (Carter et al. 2002, Johnson et al. 2010). Moreover, myotid bats appear to readily vacate dayroosts when fire approaches (Rodrigue et al. 2001). Concern also seems unwarranted for maternal colonies given the near total lack of fire in hardwood forests of the Central Hardwoods and Appalachian region from May through early August, the period for maternity colony formation to juvenile volancy and weaning. Indiana bats in the Ozarks selected areas of mature upland oak-hickory forest that had been burned with low-intensity fire in April (Womack et al. 2013). Home ranges of northern bats on the Appalachian Plateau were closer to stands that had been burned with low-intensity fire in April (Lacki et al. 2009). Insects that are consumed by bats increased in abundance following fire, and more bats roosted in burned areas than in unburned areas (Lacki et al. 2009). Bat activity was greater in stands that had been regenerated via shelterwood harvest and later burned than in unharvested and unburned Appalachian hardwoods in Ohio (Silvis et al. 2016). The propensity of Indiana bats to forage in canopy gaps, within woodland structure, and along stream corridors in the Ohio River Valley (Kniowski and Gehrt 2014), supports allowing fire to feather into drainages, which is more likely with dormant- and late growing-season fire. Litter-roosting bats (e.g., eastern red bat) have been recorded flushing from the litter in front of the fireline during dormant-season fires (Saugay et al. 1998, Moorman et al. 1999), but no study has quantified direct effects of dormant-season fire on red bats. Most dormant-season burning (Figure 7) is conducted when ambient temperatures are above $5^{\circ} \mathrm{C}$, which allows for faster arousal from torpor (Perry 2012).

There is no published research that suggests that fire during a specific season is requisite for any wildlife species in the Central Hardwoods and Appalachians. Regardless of burn timing (similar to fire frequency), some 


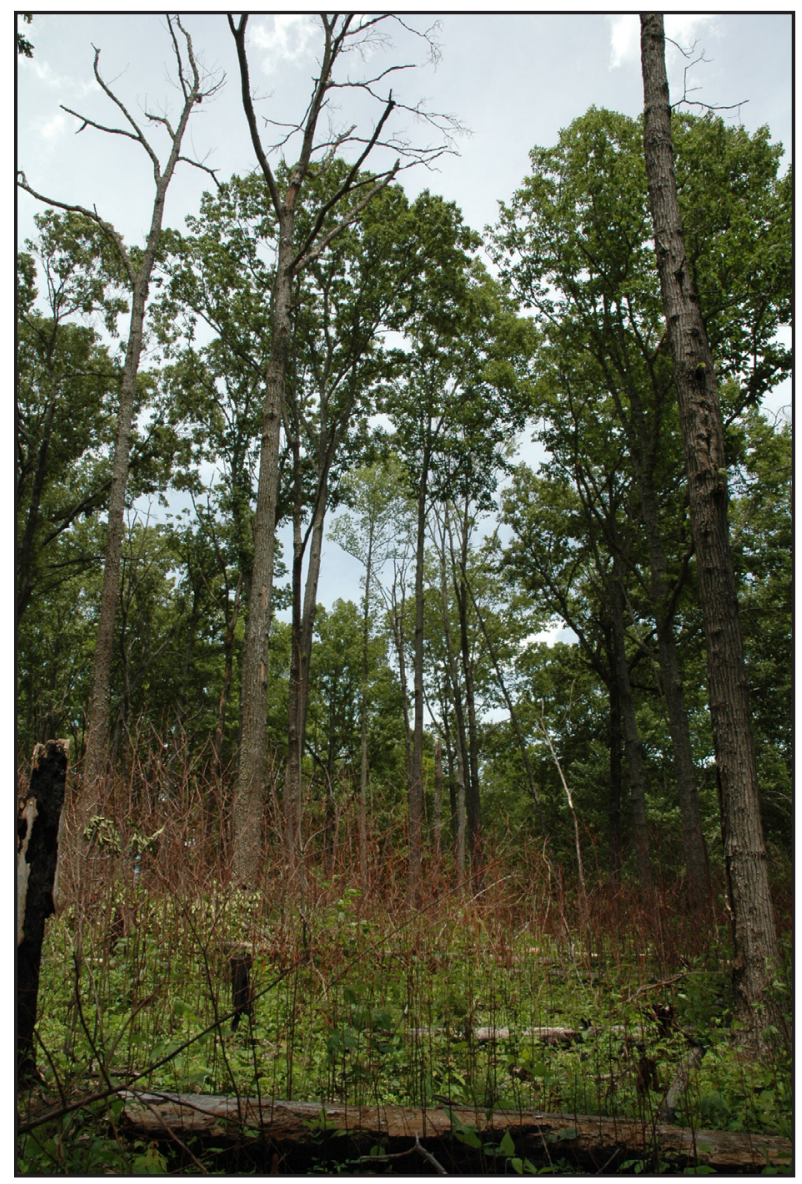

Figure 7. Prescribed fire can increase habitat suitability for several species of bats by creating snags and reducing clutter in the midstory.

species will benefit more than others, and some may be harmed more than others, which makes stating explicit objectives for the burn so important. Until research is completed on population response of various wildlife species to season of burning in the Central Hardwoods and Appalachians, recommendations for season of burning must be based on habitat conditions, fire effects on vegetation (for wildlife and ecosystem restoration), and the biology of focal species. Dormant-season fire has been used most commonly in the Central Hardwoods and Appalachians. However, growing-season fire (especially late in the growing season) must be used in many situations in order to accomplish management goals. Of course, other factors such as fire frequency and size of burn area must be considered with season of burn.

\section{Pattern of Burning and Burn Size}

Topography is diverse across the Central Hardwoods and Appalachians. Landform strongly influences soil type and moisture and the vegetation community, which influences fire-return interval, fire intensity, and season of burning. South- and west-facing slopes burn more frequently and with greater intensity than north- and east-facing slopes (Thomas-Van Gundy et al. 2007). Landform also strongly influences the wildlife community. For example, woodland salamanders (Plethodontidae) are most abundant on moist aspects and along lower slope positions (Harper and Guynn 1998, Ford et al. 2002). Concern for any negative effect of fire on these salamanders is alleviated when burning is concentrated on drier sites where fire is more common and salamanders are less numerous (Ford et al. 1999, Moorman et al. 2011).

We contend that only fire can provide landscape-level heterogeneity in some landscapes, such as the Appalachians, that otherwise largely would be an unbroken static-aged forest, particularly at present when forest management (i.e., timber harvest) now constitutes a very small proportion of any given area in the region's national forests (Sandeno 2015). Prescribed fire should be concentrated on drier sites that would burn more frequently naturally, depending on specific management objectives. However, fire should be allowed to feather into more moist environments where fuel consumption will be less complete and thus provide a mosaic of conditions and increase site heterogeneity. Relatively moist sites (e.g., southeast- and northwest-facing slopes) may be burned occasionally, according to land management objectives, but fire frequency and intensity generally should be less on those sites to provide a mosaic across time and space (from south-facing slopes around to 
north-facing slopes) and increase landscape heterogeneity and wildlife diversity.

A major consideration when managing large tracts of land is size of burn. Landscape heterogeneity, land and wildlife management objectives, public perception, and limited manpower and funds are integral factors that influence size of burns. Often, burning in the region occurs at a small scale ( $<15 \mathrm{ha})$, which can have positive effects locally, but cannot elicit landscape-level change or help perpetuate fire-dependent ecosystems (e.g., oak woodland or savanna) unless small-scale fires are well distributed throughout the landscape considered. Larger burn areas, such as those being conducted now on many national forests in the central and southern Appalachians within US Forest Service Region 8, will be necessary to affect the landscape. We are not suggesting that every fire should be $>100$ ha, but there is an economy of scale whereby relatively small burns can take as much time planning and implementing as larger burns. Therefore, to have a landscape effect with limited manpower and funds, larger burns may be more effective in achieving desired effects. Variable fire intensity is commonplace when implementing larger burns, and is especially important for site heterogeneity. Larger burns also may be necessary to ameliorate impacts from deer herbivory. Over much of the Central Appalachians, white-tailed deer densities are at levels unprecedented over the past two centuries (McShea et al. 1997). Accordingly, failure to account for the effect of herbivory following burning and failing to burn in conjunction with harvesting may prevent restoration of native flora and may negatively affect wildlife dependent on understory structure. Burning at small scales may require localized population reduction (Miller et al. 2010) or exclusion measures (Kochenderfer and Ford 2008, Royo et al. 2010) to prevent herbivory effects or, alternatively, disturbance must exceed $10 \%$ of the surrounding landscape to compensate for herbivory effects (Miller et al. 2009).

\section{RECOMMENDATIONS AND CONSIDERATIONS WHEN BURNING FOR VARIOUS WILDLIFE SPECIES IN THE CENTRAL HARDWOODS AND APPALACHIANS}

We offer the following recommendations for burning when individual species or species guilds are the focus of management (Appendix 1). Our recommendations are based on published research and personal experience. We consider fire effects on vegetation as habitat for focal species, possible direct fire effects on focal species, and the biology (life history) of focal species. We acknowledge that data are lacking with respect to various burning regimes and population-level effects for many wildlife species in the Central Hardwoods and Appalachians. Also, based on our experience and review of the literature, we contend that burning during any season and within a relatively wide range of fire intensity is better than not burning at all for species that require fire to maintain or enhance their habitat. Certainly, a lack of fire in the Central Hardwoods and Appalachians is a much larger limiting factor for species that benefit from burning than an inexact fire frequency, intensity, or timing. That said, it should be clear that, when local populations and abundance of a species is of particular interest, burning prescriptions should be congruent with the life history of the focal species in order to benefit that species as much as possible (Appendix 2). Although we do not specifically address burn size for various species, it should be recognized and accepted that where fire is used, applications separated across time and space and less rigid prescriptions with regard to timing and frequency can provide a mosaic of habitat conditions to support the biological requirements of the focal species.

\section{Songbirds}

Habitat for various forest songbirds (e.g., black-and-white warbler, worm-eating war- 
bler, Kentucky warbler, hooded warbler, and eastern towhee) that require a developed understory for nesting and foraging can be maintained with low-intensity fire on a $5 \mathrm{yr}$ to $7 \mathrm{yr}$ return interval. Burning outside late April to July will not disturb nesting, which should not limit burning hardwood systems in the Central Hardwoods and Appalachians because burn days during that time are relatively rare. Burning closed-canopy forests is unlikely to improve conditions for these birds unless the fire is intense enough to kill some overstory trees. Stands should have a broken canopy, allowing at least $20 \%$ sunlight to the forest floor or sufficient structure may not develop (McCord et al. 2014). Low-intensity fire can be used to maintain desirable structure without killing overstory trees. Low-intensity fire also does not consume small woody stems (Stribling and Barron 1995), leaving structure desirable for various winter migrants and residents (e.g., hermit thrush [Catharus guttatus Pall.] and Carolina wren [Thryothorus ludovicianus Latham]).

Birds that favor more open-canopy, woodland structure (e.g., yellow-billed cuckoo [Coccyzus americanus L.], red-headed woodpecker, eastern wood-pewee, least flycatcher [Empidonax minimus Baird Baird], great-crested flycatcher, eastern kingbird [Tyrannus tyrannus L.], pine warbler [Dendroica pinus L.], summer tanager, and orchard oriole [Icterus spurius L.]) benefit from both dormant- and growing-season fire. A fire-return interval within 6 yr to $7 \mathrm{yr}$ will be necessary on most sites to retain desirable structure for these birds. All of these species nest either in cavities or at least $3 \mathrm{~m}$ to $6 \mathrm{~m}$ aboveground.

Burning openings with considerable shrub cover on a $6 \mathrm{yr}$ to $7 \mathrm{yr}$ return interval can be used to maintain habitat for songbirds that require such structure (e.g., white-eyed vireo, gray catbird [Dumetella carolinensis L.], brown thrasher, yellow warbler [Dendroica petchia L.], chestnut-sided warbler, common yellowthroat (Geothlypis trichas L.), and yel- low-breasted chat). Late growing-season fire may be useful when some reduction in woody stem density is desired.

Early successional openings dominated with forbs, brambles, grasses, and scattered shrub cover can be maintained with late dormant-season fire on a $3 \mathrm{yr}$ to $5 \mathrm{yr}$ return interval to benefit species such as loggerhead shrike, eastern bluebird (Sialia sialis L.), bluewinged warbler, golden-winged warbler (Vermivora chrysoptera L.), prairie warbler (Dendroica discolor Vieill.), blue grosbeak (Guiraca caerulea L.), indigo bunting, field sparrow, and American goldfinch (Carduelis tristis L.). Burning just prior to spring green-up will maintain winter cover for various sparrows (American tree [Spizella arborea Wilson], chipping [S. passerine Bech.], field, savannah [Passerculus sandwichensis Gmelin], fox [Passerella iliaca Merrem], song [Melospiza melodia Wilson], white-throated [Zonotrichia albicollis Gmelin], and white-crowned [Z. leucophrys Forst.]) that overwinter in the region. Retaining winter cover is important for some species when burning is relatively widespread (Thatcher et al. 2006).

Grasslands within a grassland matrix, as well as reclaimed surface mine sites and large grassy balds, can be managed with dormantor growing-season fire on a $1 \mathrm{yr}$ to $3 \mathrm{yr}$ return interval for grassland birds (e.g., dickcissel [Spiza americana Gmelin], savannah sparrow, grasshopper sparrow (Ammodramus savannarum Gmelin), Henslow's sparrow, and eastern meadowlark [Sturnella magna L.]). Size of the area burned may be relatively large (40 ha to $50 \mathrm{ha}$ ) when maintaining habitat for grassland obligate species, and although not all of the habitat should be burned in one year, it is important that some portion of the habitat is burned each year to provide a mosaic of burned and unburned area within the $1 \mathrm{yr}$ to 3 yr fire-return interval (Hovick et al. 2012, 2015). Frequent dormant-season fire generally maintains a grassland community. However, when woody encroachment is problematic, 
and especially when burn size is large, burning during the late growing season should be considered to avoid disrupting nesting. This is critical for grassland birds in this region because multiple successful nests may be necessary to maintain populations (Giocomo et al. 2008). A combination of both dormant- and late growing-season fire should provide increased diversity and increased grassland bird populations (Hovick et al. 2015).

\section{Northern Bobwhite}

Late dormant-season or early growing-season fire on a 2 yr to 4 yr return interval can be used to maintain early successional vegetation in openings and oak savannas. Peak nesting for bobwhite in the region occurs June to July (Roseberry and Klimstra 1984); therefore, early growing-season fire (April to May) poses relatively little direct effect on bobwhite. Moderate-intensity fire often is necessary to top-kill relatively large woody stems $(7 \mathrm{~cm}$ $\mathrm{dbh}$ to $15 \mathrm{~cm} \mathrm{dbh).} \mathrm{Late} \mathrm{growing-season} \mathrm{fire}$ implemented in September and October (after peak nesting) may be used to help set back woody composition, but burn areas should be $<12$ ha (unless the fire is low-intensity and patchy) because burning at this time may reduce woody cover available in winter, which has been identified as a major limiting factor for bobwhite in the region (Brooke et al. 2015, Peters et al. 2015, Unger et al. 2015).

\section{Wild Turkey}

Low-intensity prescribed fire on a 3 yr to 5 yr return interval may be used to maintain suitable understory structure in broken-canopy hardwood forests and woodlands for nesting and brood-rearing wild turkey (McCord et al. 2014). Burning during the wild turkey nesting and brood-rearing season (April through early June) has been a concern of land managers. No negative population-level effects have been reported following early growing-season fire in longleaf pine systems (Kilburg et al. 2014).
However, wild turkeys selectively nest in hardwood drainages dissecting longleaf stands that are burned frequently. Better cover for nesting exists in the drainages because they do not burn as often or as completely as the surrounding longleaf uplands and therefore fewer nests are exposed to burning (Kilburg et al. 2014). Wild turkey nest sites in upland hardwood forests are located more randomly and not concentrated in drainages (Wunz and Pack 1992). Although nesting wild turkey hens readily re-nest when disturbed during the laying period or early in incubation (Dickson 1992), it is possible that burning upland hardwoods during the nesting season could impact nest success more than burning in pine systems, especially if burned areas are relatively large. Burning outside the nesting season alleviates any concern for disrupting wild turkey nests in upland hardwoods. Wild turkeys are attracted for foraging to sites burned during the dormant season (Kilburg et al. 2015). Dormant-season burning also is more advantageous in providing brooding cover because burning during the early growing season does not allow sufficient regrowth to provide cover for broods by late May and June when most broods appear (Sisson and Speake 1994). Oldfields and other early successional areas, including oak savannas, that may be used for nesting or brood-rearing turkeys can be maintained with low- to moderate-intensity fire without damaging residual trees in a savanna. Burning during the late growing season expands opportunities for burning, provides foraging areas in early fall, and may provide better control of woody sprouting than dormant-season fire (Gruchy et al. 2009).

\section{Ruffed Grouse}

Low-intensity, dormant-season fire on a 6 yr to 8 yr return interval can be used in mature oak-hickory stands with a broken canopy (allowing $20 \%$ to $40 \%$ sunlight to enter the stand) to maintain desirable stem density and understory cover for ruffed grouse (Jones and 
Harper 2007, Jones et al. 2008). Young forest stands without overstory trees can be managed explicitly for ruffed grouse cover with moderate-intensity, dormant-season fire on a $15 \mathrm{yr}$ to 20 yr fire-return interval. We do not recommend early growing-season (mid-April through early June) burning where ruffed grouse is a focal species, especially if burn units are large. The re-nesting rate of ruffed grouse in oak-hickory forests of the central and southern Appalachians is extremely low (Devers et al. 2007, Jones et al. 2015), and fecundity is a limiting factor for ruffed grouse in the southern Appalachians (Jones et al. 2015).

\section{White-Tailed Deer}

Low-intensity dormant- or growing-season fire on a 3 yr to $5 \mathrm{yr}$ return interval may be used in mature stands with a broken canopy to stimulate forage for white-tailed deer (Lashley et al. 2011). Using low-intensity fire in closed-canopy stands may provide some increase in forage availability, but the increase may be negligible (Shaw et al. 2010, Lashley et al. 2011). Early successional openings can be burned with low- to moderate-intensity fire to maintain forage availability and cover for fawning. Burning for white-tailed deer should be conducted outside the fawning season (May through July), given the reliance of females on associated cover at that time (Lashley et al. 2015a).

\section{Bats}

Moderate- to high-intensity dormant-season fire may be used to create snags and increase day-roost sites for species such as Indiana bat and northern long-eared bat in mature hardwoods (Johnson et al. 2009, Johnson et al. 2010, Ford et al. 2015). Low-intensity fire can be used during the dormant or early growing season on a $5 \mathrm{yr}$ to $7 \mathrm{yr}$ return interval to reduce the midstory and improve foraging conditions for most bat species in stands with a broken canopy structure. Forest openings can be burned on a 2 yr to $5 \mathrm{yr}$ interval to maintain open areas for foraging bats (Loeb and O’Keefe 2011).

\section{Reptiles and Amphibians}

Dormant-season burning in open forest, woodland, or savanna encourages vegetation structure, cover, and microclimate beneficial for several reptiles, such as eastern fence lizard and timber rattlesnake, without posing any negative direct effect (Moseley et al. 2003, Keyser et al. 2004, Greenberg and Waldrop 2008, Matthews et al. 2010). Litter removal and greater ground temperatures following fires likely create thermoregulatory conditions favorable for lizards (Moseley et al. 2003). Overstory mortality following intense fires also generates down wood that may be used as basking sites by lizards and large-bodied snakes (Matthews et al. 2010). Low-intensity fire does not consume pre-existing large, coarse woody debris that is important as cover for many herpetofauna. Some snakes (e.g., timber rattlesnakes) are most vulnerable to fire soon after they emerge from winter hibernacula. Early growing-season fire poses a risk to these animals, especially when burning near known hibernacula and when burning relatively large areas (Figure 8).

Dormant-season burning avoids direct risk to terrestrial salamanders that are more active during the early growing season. Drier site conditions following burns, especially when in combination with overstory reduction through fire-induced tree mortality or timber harvest, may lead to reduced abundance or reduced aboveground activity of salamanders for at least one year post burning (Matthews et al. 2010, O'Donnell et al. 2015). However, burning sites that are more predisposed to fire (e.g., south- and west-facing slopes) can lead to increased assemblages of plant and wildlife species across the landscape without threatening salamander populations on more moist micro- 


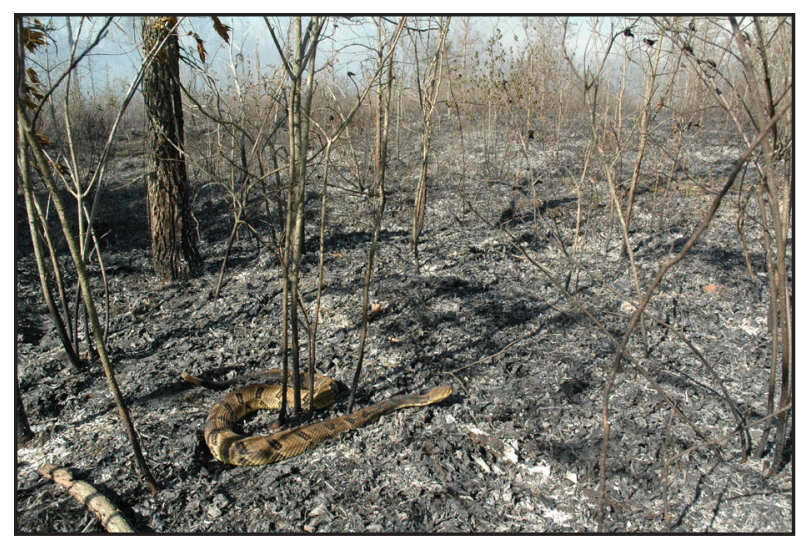

Figure 8. If hibernacula occur on the site, burning during the early growing season is more likely to have a direct effect on several snake species than burning during the dormant season before they emerge. However, burning during the early growing season does not necessarily mean snakes are going to die. This timber rattlesnake was observed immediately post burning in early April.

sites where they occur most readily (Moorman et al. 2011).

\section{CONCLUSIONS AND SUGGESTIONS FOR FUTURE RESEARCH}

We still have much to learn about the ecology of fire in hardwood forests in the Central Hardwoods and Appalachian regions. Historical evidence shows that fire once was prevalent on various sites throughout these regions. It is important for natural resource managers to recognize how fire is a fundamental ecological process in any fire-prone plant community and that it often is the primary driver in ecosystem function. Findings from recent research and management efforts show much promise for ecosystem restoration and enhanced wildlife management using prescribed fire. However, success of such efforts may be evasive and the effects may not be clear or realized if objectives for burning are not thoroughly considered and clearly articulated, and the fire not properly implemented.

Fire causes change, which, under any circumstance, is good for some wildlife species and not good for others. We must recognize the utility of fire to change specific sites and landscapes in a manner that will accomplish specific management objectives that should be planned and monitored for success. We view a lack of fire in these regions as a limiting factor for increased landscape heterogeneity and biological diversity, as well as a limitation to increased abundance of many wildlife species.

Information is lacking on population response of many wildlife species to fire, which is obviously important, especially for declining species. Relatively basic questions on how plant communities and various wildlife species respond to fire frequency and season of burning need additional research. Also, the conservation community would benefit from a better understanding of landscape-level wildlife response to small-scale burning, as well as landscape-level wildlife response to large-scale application of prescribed fire. Of course, longterm data are needed to answer most questions. Although we recognize that relatively frequent and sometimes intensive fire may be necessary to elicit compositional change in the plant community, we note that the suitable prescription to maintain the resulting plant community may be quite different. We have gained information from dendrochronological data to guide initial attempts, but we are just beginning to put this information into practice in hardwood ecosystems. The wildlife response to this management is yet to be realized.

\section{ACKNOWLEDGEMENTS}

The manuscript was improved by the insightful comments and suggestions provided by K. Russell and two anonymous reviewers. 


\section{LITERATURE CITED}

Amelon, S.K., F.R. Thompson III, and J.J. Millspaugh. 2014. Resource utilization by foraging eastern red bats (Lasiurus borealis) in the Ozark region of Missouri. Journal of Wildlife Management 78: 483-493. doi: 10.1002/jwmg.685

Artman, V.L., E.K. Sutherland, and J.F. Downhower. 2001. Prescribed burning to restore mixedoak communities in southern Ohio: effects on breeding-bird populations. Conservation Biology 15: 1423-1434. doi: 10.1046/j.1523-1739.2001.00181.x

Bakermans, M.H., A.D. Rodewald, and A.C. Vitz. 2012. Influence of forest structure on density and nest success of mature forest birds in managed landscapes. Journal of Wildlife Management 76: 1225-1234. doi: 10.1002/jwmg.349

Barrioz, S.A., P.D. Keyser, D.S. Buckley, D.A. Buehler, and C.A. Harper. 2013. Vegetation and avian response to oak savanna restoration in the Mid-South USA. American Midland Naturalist 169: 194-213. doi: 10.1674/0003-0031-169.1.194

Beaupre, S.J., and L.E. Douglas. 2012. Responses of timber rattlesnakes to fire: lessons from two prescribed burns. Pages 192-204 in: D.C. Dey, M.C. Stambaugh, S.L. Clark, and C.J. Schweitzer, editors. Proceedings of the 4th Fire in Eastern Oak Forests Conference, 17-19 May 2011, Springfield, Missouri, USA. USDA Forest Service General Technical Report NRS-P-102, Northern Research Station, Newtown Square, Pennsylvania, USA.

Blake, J.G. 2004. Effects of prescribed burning on distribution and abundance of birds in a closed-canopy oak-dominated forest, Missouri, USA. Biological Conservation 121: 519531. doi: 10.1016/j.biocon.2004.06.021

Boyles, J.G., and D.P. Aubrey. 2006. Managing forests with prescribed fire: implications for a cavity-dwelling bat species. Forest Ecology and Management 222: 108-115. doi: 10.1016/j. foreco.2005.09.024

Bowen, B.J., and J.S. Pate. 1993. The significance of root starch in post-fire shoot recovery of the resprouter Stirlingia latifolia R. Br. (Proteaceae). Annals of Botany 72: 7-16. doi: 10.1006/anbo.1993.1075

Brawn, J.D. 2006. Effects of restoring oak savannas on bird communities and populations. Conservation Biology 20: 460-469. doi: 10.1111/j.1523-1739.2006.00310.x

Brennan, A., R.T. Engstrom, W.E. Palmer, S.M. Herman, G.A Hurst, L.W. Burger, and C.L. Hardy. 1998. Whither wildlife without fire. Transactions of the 63rd North American Wildlife and Natural Research Conference 63:402-414.

Briggler, J. 2014. Prescribed fire effects on herpetofauna in Missouri. Missouri Natural Areas Newsletter 14: 27-30.

Brody, A.J., and J.N. Stone. 1987. Timber harvest and black bear population dynamics in a southern Appalachian forest. Pages 243-250 in: Bears: their biology and management, volume 7. International Association for Bear Research and Management, Williamsburg, Virginia, USA.

Brooke, J.M., D.C. Peters, A.M. Unger, E.P. Tanner, C.A. Harper, P.D. Keyser, J.D. Clark, and J.J. Morgan. 2015. Habitat manipulation influences northern bobwhite resource selection on a reclaimed surface mine. Journal of Wildlife Management 79: 1264-1276. doi: 10.1002/ jwmg.944

Brose, P.H., and D. Van Lear. 1998. Responses of hardwood advance regeneration to seasonal prescribed fires in oak-dominated shelterwood stands. Canadian Journal of Forest Research 28: 331-339. doi: 10.1139/x97-218 
Brose, P.H., T. Schuler, D. Van Lear, and J. Berst. 2001. Bringing fire back: the changing regimes of the Appalachian mixed-oak forests. Journal of Forestry 99: 30-35.

Brose, P.H., D.C. Dey, and T.A. Waldrop. 2014. The fire-oak literature of eastern North America: synthesis and guidelines. USDA Forest Service General Technical Report NRS-135, Northern Research Station, Newtown Square, Pennsylvania, USA.

Burton, J.A., S.W. Hallgren, and M.W. Palmer. 2010. Fire frequency affects structure and composition of xeric forests of eastern Oklahoma. Natural Areas Journal 30: 370-379. doi: 10.3375/043.030.0401

Carter, T.C., W.M. Ford, and M.A. Menzel. 2002. Fire and bats in the Southeast and Mid-Atlantic: more questions than answers? Pages 139-143 in: W.M. Ford, K.R. Russell, and C.E. Moorman, editors. Proceedings of a special workshop on the role of fire for nongame wildlife management and community restoration: traditional uses and new directions. USDA Forest Service General Technical Report NE-288, Northern Research Station, Newtown Square, Pennsylvania, USA.

Cohen, D., B. Dellinger, R. Klein, and B. Buchanan. 2007. Patterns in lightning-caused fires at Great Smoky Mountains National Park. Fire Ecology 3(2): 68-82. doi: 10.4996/fireecology. 0302068

Cook, R.C., J.G. Cook, D.J. Vales, B.K. Johnson, S.M. McCorquondale, L.A. Shipley, R.A. Riggs, L.L. Irwin, S.L. Murphie, K.A. Schoenecker, F. Geyer, P.B. Hall, R.D. Spencer, D.A. Immell, D.H. Jackson, B.L. Tiller, P.J. Miller, and L. Schmitz. 2013. Regional and seasonal patterns of nutritional condition and reproduction in elk. Wildlife Monographs 184: 1-45. doi: 10.1002/wmon.1008

Cox, J., and C. Jones. 2007. Home range and survival characteristics of male Bachman's sparrow in an old-growth forest managed with breeding-season burns. Journal of Field Ornithology 119: 1-8. doi: 10.1111/j.1557-9263.2007.00113.x

Cox, J., and B. Widener. 2008. Lightning-season burning: friend or foe of breeding birds? Tall Timbers Research Station Miscellaneous Publication 17, Tall Timbers Research Station and Land Conservancy, Tallahassee, Florida, USA.

Devers, P.K., D.F. Stauffer, G.W. Norman, D.E. Steffen, D.W. Whitaker, J. Sole, T. Allen, S. Bittner, D.A. Buehler, J.W. Edwards, D. Figert, S. Friedhoff, W.M. Giuliano, C.A. Harper, W. Igo, R. Kirkpatrick, M. Seamster, H. Spiker, D. Swanson, and B. Tefft. 2007. Ruffed grouse population ecology in the Appalachian region. Wildlife Monographs Number 168.

Dey, D.C., and C.J. Schweitzer. 2015. Timing fire to minimize damage in managing oak ecosystems. Pages 143-153 in: A.G. Holley, K.F. Connor, and J.D. Haywood, editors. Proceedings of the 17th Biennial Southern Silvicultural Research Conference. USDA Forest Service General Technical Report SRS-203, Southern Research Station, Asheville, North Carolina, USA.

Dickinson, M.B. 2010. Burning and bats: fire's effect on the endangered Indiana bat. Fire Science Brief 109: 1-5.

Dickinson, M.B., M.J. Lacki, and D.R. Cox. 2009. Fire and the endangered Indiana bat. Pages 51-75 in: T.F. Hutchison, editor. Proceedings of the 3rd Fire in Eastern Oak Forests Conference. USDA Forest Service General Technical Report GTR-NRS-P-46, Northern Research Station, Newtown Square, Pennsylvania, USA.

Dickson, J.G. 1992. The wild turkey: biology and management. Stackpole Books, Harrisburg, Pennsylvania, USA.

Drewa, P.B., W.J. Platt, and E.B. Moser. 2002. Fire effects on resprouting of shrubs in headwaters of southeastern longleaf pine savannas. Ecology 83: 755-767. doi: 10.1890/0012-9658(2002)083[0755:FEOROS]2.0.CO;2 
Dyer, J.M. 2006. Revisiting the deciduous forests of eastern North America. Bioscience 56: 341-352. doi: 10.1641/0006-3568(2006)56[341:RTDFOE]2.0.CO;2

Engstrom, R.T., P.D. Vickery, D.W. Perkins, and W.G. Shriver. 2005. Effects of fire regime on birds in southeastern pine savannas and native prairies. Studies in Avian Biology 30: 147160.

Flatley, W.T., C.W. Lafon, H.D. Grissino-Mayer, and L.B. LaForest. 2013. Fire history, related to climate and land use in three southern Appalachian landscapes in the eastern United States. Ecological Applications 23: 1250-1266. doi: 10.1890/12-1752.1

Floyd, T.M., K.R. Russell, C.E. Moorman, D.H. Van Lear, D.C. Guynn Jr., and J.D. Lanham. 2002. Effects of prescribed fire on herpetofauna within hardwood forests of the upper Piedmont of South Carolina: a preliminary analysis. Pages 123-127 in: K.W. Outcalt, editor. Proceedings of the 11th Biennial Southern Silvicultural Research Conference. USDA Forest Service General Technical Report SRS-48, Southern Research Station, Asheville, North Carolina, USA.

Ford, W.M., M.A. Menzel, D.W. McGill, J. Laerm, and T.S. McCay. 1999. Effects of a community restoration fire on small mammals and herpetofauna in the southern Appalachians. Forest Ecology and Management 114: 233-243. doi: 10.1016/S0378-1127(98)00354-5

Ford, W.M., J.M. Menzel, M.A. Menzel, J.W. Edwards, and J.C. Kilgo. 2006. Presence and absence of bats across habitat scales in the upper Coastal Plain of South Carolina. Journal of Wildlife Management 70: 1174-1184. doi: 10.2193/0022-541X(2006)70[1200:PAAOBA] 2.0.CO;2

Ford, W.M., M.A. Menzel, and R.H. Odom. 2002. Elevation, aspect, and cove size effects on woodland salamanders in the southern Appalachians. Southeastern Naturalist 1: 315-324. doi: 10.1656/1528-7092(2002)001[0315:EAACSE]2.0.CO;2

Ford, W.M., J.L. Rodrigue, E.L. Rowan, S.B. Castleberry, and T.M. Schuler. 2010. Woodland salamander response to two prescribed fires in the central Appalachians. Forest Ecology and Management 260: 1003-1009. doi: 10.1016/j.foreco.2010.06.022

Ford, W.M., A. Silvis, J.B. Johnson, J.W. Edwards, and M. Karp. 2016. Northern long-eared bat day-roosting and prescribed fire in the central Appalachians, USA. Fire Ecology 12(2): 1327. doi: 10.4996/fireecology.1202013

Frost, C.C. 1998. Presettlement fire frequency regimes of the United States: a first approximation. Proceedings of the Tall Timbers Fire Ecology Conference 20: 70-81.

Giocomo, J.J., E.D. Moss, D.A. Buehler, and W.G. Minser. 2008. Nesting biology of grassland birds at Fort Campbell, Kentucky and Tennessee. The Wilson Journal of Ornithology 120: 111-119. doi: 10.1676/06-022.1

Glitzenstein, J.S., W.J. Platt, and D.R. Streng. 1995a. Effects of fire regime and habitat on tree dynamics in north Florida longleaf pine savannas. Ecological Monographs 65: 441-476. doi: $10.2307 / 2963498$

Glitzenstein, J.S., D.R. Streng, and W.J. Platt. 1995b. Evaluating the effects of season of burn on vegetation in longleaf pine savannas. Nongame Wildlife Project Report, Florida Game and Freshwater Fish Commission, Tallahassee, Florida, USA.

Glitzenstein, J.S., D.R. Streng, R.E. Masters, K.M. Robertson, and S.M. Hermann. 2015. Fire-frequency effects on vegetation in north Florida pinelands: another look at the long-term Stoddard Fire research plots at Tall Timbers Research Station. Forest Ecology and Management 264: 197-209. doi: 10.1016/j.foreco.2011.10.014 
Greenberg, C.H. 2000. Fire, habitat structure and herpetofauna in the southeast. Pages 91-99 in: W.M. Ford, K.R. Russell, and C.E. Moorman, editors. Proceedings of a special workshop on the role of fire for nongame wildlife management and community restoration: traditional uses and new directions. USDA Forest Service General Technical Report NE-288, Northern Research Station, Newtown Square, Pennsylvania, USA.

Greenberg, C.H., A.L. Tomcho, J.D. Lanham, T.A. Waldrop, J. Tomcho, R.J. Phillips, and D. Simon. 2007. Short-term effects of fire and other fuel reduction treatments on breeding birds in a southern Appalachian upland hardwood forest. Journal of Wildlife Management 71: 19061916. doi: 10.2193/2006-070

Greenberg, C.H., and T.A. Waldrop. 2008. Short-term response of reptiles and amphibians to prescribed fire and mechanical fuel reduction in a southern Appalachian upland hardwood forest. Forest Ecology and Management 255: 2883-2893. doi: 10.1016/j.foreco.2008.01.064

Greenberg, C.H., T.A. Waldrop, J. Tomcho, R.J. Phillips, and D. Simon. 2013. Bird response to fire severity and repeated burning in upland hardwood forest. Forest Ecology and Management 304: 80-88. doi: 10.1016/j.foreco.2013.04.035

Gruchy, J.P., C.A. Harper, and M.J. Gray. 2009. Methods for controlling woody invasion into CRP fields in Tennessee. Pages 315-341 in S.B. Cederbaum, B.C. Faircloth, T.M. Terhune, J.J. Thompson, and J.P. Carroll, editors. Proceedings of Gamebird 2006. Quail VI and Perdix XII. Warnell School of Forestry and Natural Resources, University of Georgia, Athens, USA.

Gruchy, J.P., and C.A. Harper. 2014. Effects of management practices on northern bobwhite habitat. Journal of the Southeastern Association of Fish and Wildlife Agencies 1: 133-141.

Hare, R.C. 1965. Contribution of bark to fire resistance of Southern trees. Journal of Forestry 63: 248-251.

Harmon, M.E. 1984. Survival of trees after low-intensity surface fires in Great Smoky Mountains National Park. Ecology 65: 796-802. doi: 10.2307/1938052

Harper, C.A. 2007. Strategies for managing early successional habitat for wildlife. Weed Technology 21: 932-937. doi: 10.1614/WT-07-024.1

Harper, C.A., and D.C. Guynn. 1998. Factors affecting salamander density and distribution within four forest types in the southern Appalachian Mountains. Forest Ecology and Management 114: 245-252. doi: 10.1016/S0378-1127(98)00355-7

Hermann, S.M., J.S. Kush, J.C. Gilbert, and R.J. Barlow. 2015. Burning for conservation values: should the goal be to mimic a natural fire regime? Pages 164-171 in: A.G. Holley, K.F. Conner, and J.D. Haywood, editors. Proceedings of the 17th Biennial Southern Silvicultural Research Conference. USDA Forest Service e-General Technical Report SRS-203, Southern Research Station, Asheville, North Carolina, USA.

Holcomb, E.D., P.D. Keyser, and C.A. Harper. 2014. Responses of planted native warm-season grasses and associated vegetation to seasonality of fire in the southeastern US. Southeastern Naturalist 13: 221-236. doi: 10.1656/058.013.0221

Holoubek, N.S., and W.E. Jensen. 2015. Avian occupancy varies with habitat structure in oak savanna of the south-central United States. Journal of Wildlife Management 79: 458-468. doi: 10.1002/jwmg.849

Hovick, T.J., J.R. Miller, S.J. Dinsmore, D.M. Engle, D.M. Debinski, and S.D. Fuhlendorf. 2012. Effects of fire and grazing on grasshopper sparrow nest survival. Journal of Wildlife Management 76: 19-27. doi: 10.1002/jwmg.243

Hovick, T.J., R.D. Elmore, S.D. Fuhlendorf, D.M. Engle, and R.G. Hamilton. 2015. Spatial heterogeneity increases diversity and stability in grassland bird communities. Ecological Applications 23: 662-672. doi: 10.1890/14-1067.1 
Howe, H.F. 2011. Fire season and prairie forb richness in a 21-y experiment. Ecoscience 18: 317-328. doi: 10.2980/18-4-3421

Howey, C.A.F., and W.M. Roosenburg. 2013. Effects of prescribed fire on the eastern box turtle (Terrapene carolina carolina). Northeastern Naturalist 20: 493-497. doi: 10.1656/045.020. 0312

Hunter, M.L., and F.A. Schmiegelow. 2011. Wildlife, forests, and forestry: principles of managing forests for biological diversity. Second edition. Prentice Hall, Upper Saddle River, New Jersey, USA.

Hunter, W.C., D.A. Buehler, R.A. Canterbury, J.L. Confer, and P.B. Hamel. 2001. Conservation of disturbance-dependent birds in eastern North America. Wildlife Society Bulletin 29: 440455.

Johnson, A.S., and P.E. Hale. 2002. The historical foundations of prescribed burning for wildlife: a southeastern perspective. Pages 11-23 in: W.M. Ford, K.R. Russell, and C.E. Moorman, editors. Proceedings of a special workshop on the role of fire for nongame wildlife management and community restoration: traditional uses and new directions. USDA Forest Service General Technical Report NE-288, Northern Research Station, Newtown Square, Pennsylvania, USA.

Johnson, J.B., J.W. Edwards, and W.M. Ford. 2012. Nocturnal activity patterns of Northern Myotis (Myotis septentrionalis) during the maternity season in West Virginia (USA). Acta Chiropterologica 13: 391-397. doi: 10.3161/150811011X624866

Johnson, J.B., J.W. Edwards, W.M. Ford, and J.E. Gates. 2009. Roost tree selection by Northern Myotis (Myotis septentrionalis) maternity colonies following prescribed fire in a central Appalachian Mountains hardwood forest. Forest Ecology and Management 258: 233-242. doi: 10.1016/j.foreco.2009.04.008

Johnson, J.B., W.M. Ford, J.W. Edwards, J.L. Rodrigue, and C.L. Johnson. 2010. Roost selection by male Indiana Myotis following forest fires in central Appalachian hardwoods forests. Journal of Fish and Wildlife Management 1: 111-121. doi: 10.3996/042010-JFWM-007

Jones, B.C., and C.A. Harper. 2007. Ruffed grouse (Bonasa umbellus) use of stands harvested via alternative regeneration techniques in the southern Appalachians. Pages 373-382 in: D.S. Buckley and W.K. Clatterbuck, editors. Proceedings of the 15th Central Hardwood Forest Conference. USDA Forest Service General Technical Report GTR-SRS-101, Southern Research Station, Asheville, North Carolina, USA.

Jones, B.C., J.F. Kleitch, C.A. Harper, and D.A. Buehler. 2008. Ruffed grouse brood habitat use in a mixed hardwood forest: implications for forest management in the Appalachians. Forest Ecology and Management 255: 3580-3588. doi: 10.1016/j.foreco.2008.02.019

Jones, B.C., J.L. Kleitch, C.S. Dobey, D.A. Buehler, and C.A. Harper. 2015. Ruffed grouse reproductive ecology and nest site selection in western North Carolina. Journal of the Southeastern Association of Fish and Wildlife Agencies 2: 193-201.

Kabrick, J.M., D.C. Dey, C.O. Kinkead, B.O. Knapp, M. Leahy, M.G. Olson, M.C. Stambaugh, and A.P. Stevenson. 2014. Silvicultural considerations for managing fire-dependent oak woodland ecosystems. USDA Forest Service General Technical Report GTR-NRS-P-142, Northern Research Station, Newtown Square, Pennsylvania, USA.

Kendrick, S.W., P.A. Porneluzi, F.R. Thompson III, D.L. Morris, J.M. Haslerig, and J. Faaborg. 2015. Stand-level bird response to experimental forest management in the Missouri Ozarks. Journal of Wildlife Management 79: 50-59. doi: 10.1002/jwmg.804 
Keyser, P.D., D.J. Sausville, W.M. Ford, D.J. Schwab, and P.H. Brose. 2004. Prescribed fire impacts to amphibians and reptiles in shelterwood-harvested oak-dominated forests. Virginia Journal of Science 55: 160-167.

Kilburg, E.L., C.E. Moorman, C.S. Deperno, D. Cobb, and C.A. Harper. 2014. Wild turkey nest survival and nest-site selection in the presence of growing-season prescribed fire. Journal of Wildlife Management 78: 1033-1039. doi: 10.1002/jwmg.751

Kilburg, E.L., C.E. Moorman, C.S. DePerno, D. Cobb, and C.A. Harper. 2015. Wild turkey pre-nesting resource selection in a landscape managed with frequent prescribed burns. Southeastern Naturalist 14: 137-146. doi: 10.1656/058.014.0114

Kirkland, G.L., Jr., H.W. Snoddy, and T.L. Amsler. 1996. Impact of fire on small mammals and amphibians in a central Appalachian deciduous forest. American Midland Naturalist 135: 253-260. doi: 10.2307/2426707

Knapp, E.E., B.L. Estes, and C.N. Skinner. 2009. Ecological effects of prescribed fire season: a literature review and synthesis for managers. USDA Forest Service General Technical Report PSW-GTR-224, Pacific Southwest Research Station, Albany, California, USA.

Knapp, B.O., K. Stephan, and J.A. Hubbart. 2015. Structure and composition of an oak-hickory forest after over 60 years of repeated prescribed burning in Missouri, USA. Forest Ecology and Management 344: 95-109. doi: 10.1016/j.foreco.2015.02.009

Kniowski, A.B., and S.D. Gehrt. 2014. Home range and habitat selection of the Indiana bat in an agricultural landscape. Journal of Wildlife Management 78: 503-512. doi: 10.1002/ jwmg.677

Kochenderfer, J.N., and W.M. Ford. 2008. Utility of wire cages, tree shelters, and repellents to minimize herbivory to oak by white-tailed deer. USDA Forest Service Research Paper NRS5, Northern Research Station, Newtown Square, Pennsylvania, USA.

Lacki, M.J., D.R. Cox, L.E. Dodd, and M.B. Dickinson. 2009. Response of Northern bats (Myotis septentrionalis) to prescribed fires in eastern Kentucky forests. Journal of Mammalogy 90: 1165-1175. doi: 10.1644/08-MAMM-A-349.1

Landhausser, S.M., and V.J. Lieffers. 2002. Leaf area removal, root retention and carbohydrate reserves in a clonal tree species following above-ground disturbance. Journal of Ecology 90: 658-665. doi: 10.1046/j.1365-2745.2002.00699.x

Lashley, M.A., C.A. Harper, G.E. Bates, and P.D. Keyser. 2011. Forage availability for whitetailed deer following silvicultural treatments in hardwood forests. Journal of Wildlife Management 75: 1467-1476. doi: 10.1002/jwmg. 176

Lashley, M.A., M.C. Chitwood, R. Kays, C.A. Harper, C.S. DePerno, and C.E. Moorman. $2015 a$. Prescribed fire affects female white-tailed deer habitat use during summer lactation. Forest Ecology and Management 348: 220-225. doi: 10.1016/j.foreco.2015.03.041

Lashley, M.A., M.C. Chitwood, C.A. Harper, C.E. Moorman, and C.S. DePerno. 2015b. Variability in fire prescriptions to promote wildlife foods in the longleaf pine ecosystem. Fire Ecology 11(3): 62-79.

Lewis, J.B., D.A. Murphy, and J. Ehrenreich. 1964. Effects of burning dates on vegetative production on Ozark forests. Pages 63-72 in: Proceedings of the 18th Annual Conference of the Southeastern Association of Game and Fish Commissioners, Clearwater, Florida, USA.

Loeb, S.C., and J.M. O'Keefe. 2011. Bats and gaps: the role of early successional patches in the roosting and foraging ecology of bats. Pages 167-189 in: C.H. Greenberg, B. Collins, and F.R. Thompson, editors. Sustaining young forest communities. Springer, New York, New York, USA. doi: 10.1007/978-94-007-1620-9_10 
Marschall, J.M., R.P. Guyette, M.C. Stambaugh, and A.P. Stevenson. 2014. Fire damage effects on red oak timber product value. Forest Ecology and Management 320: 182-189. doi: 10.1016/j.foreco.2014.03.006

Masters, R.E. 2006. The importance of shortleaf pine for wildlife and diversity in mixed oakpine forests and pine-grassland woodlands. Pages 35-46 in: J.M. Kabrick, D.C. Dey, and D. Gwaze, editors. Shortleaf pine restoration and ecology in the Ozarks - proceedings of a symposium. USDA Forest Service General Technical Report NRS-P-15, Northern Research Station, Newtown Square, Pennsylvania, USA.

Matthews, C.E., C.E. Moorman, C.H. Greenberg, and T.A. Waldrop. 2009. Response of soricid populations to repeated fires and fuel reduction treatments in the southern Appalachian Mountains. Forest Ecology and Management 257: 1939-1944. doi: 10.1016/j.foreco.2009.02.006

Matthews, C.E., C.E. Moorman, C.H. Greenberg, and T.A. Waldrop. 2010. Response of herpetofauna to repeated fires and fuel reduction treatments. Journal of Wildlife Management 74: 1301-1310. doi: 10.1111/j.1937-2817.2010.tb01251.x

McCord, J.M., C.A. Harper, and C.H. Greenberg. 2014. Brood cover and food resources for wild turkeys following silvicultural treatments in mature upland hardwoods. Wildlife Society Bulletin 38: 265-272. doi: 10.1002/wsb.403

McShea, W.M., H.B. Underwood, and J.H. Rappole. 1997. The science of overabundance: deer ecology and population management. Smithsonian Institution Press, Washington, D.C., USA.

McShea, W.M., and W.J. Healy. 2003. Oak forest ecosystems: ecology and management for wildlife. Johns Hopkins University Press, Baltimore, Maryland, USA.

Miller, B.F., T.A. Campbell, B.R. Laseter, W.M. Ford, and K.V. Miller. 2009. White-tailed deer herbivory and timber-harvesting rates: implications for regeneration success. Forest Ecology and Management 258: 1067-1072. doi: 10.1016/j.foreco.2009.05.025

Miller, B.F., T.A. Campbell, B.R. Laseter, W.M. Ford, and K.V. Miller. 2010. A test of localized management for reducing white-tailed deer herbivory in central Appalachian regeneration sites. Journal of Wildlife Management 74: 370-378. doi: 10.2193/2009-221

Moorman, C.E., K.R. Russell, M.A. Menzel, S.M. Lohr, J.E. Ellenberger, and D.H. Van Lear. 1999. Bats roosting in deciduous leaf litter. Bat Research News 40: 74-75.

Moorman, C.E., K.R. Russell, and C.H. Greenberg. 2011. Reptile and amphibian response to hardwood forest management and early successional habitat. Pages 191-208 in: C.H Greenberg, B.S. Collins, and F.R. Thompson III, editors. Sustaining young forest communities. Springer Publishing, New York, New York, USA. doi: 10.1007/978-94-007-1620-9_11

Moseley, K.R., S.B. Castleberry, and S.H. Schweitzer. 2003. Effects of prescribed fire on herpetofauna in bottomland hardwood forests. Southeastern Naturalist 2: 475-486. doi: 10.1656/1528-7092(2003)002[0475:EOPFOH]2.0.CO;2

Nowacki, G.J., and M.D. Abrams. 2008. The demise of fire and "mesophication" of forests in the eastern United States. Bioscience 58: 123-138. doi: 10.1641/B580207

O’Donnell, K.M., F.R. Thompson, and R.D. Semlitsch. 2015. Prescribed fire and timber harvest effects on terrestrial salamander abundance, detectability, and microhabitat use. Journal of Wildlife Management 79: 766-775. doi: 10.1002/jwmg.884

Perry, R.W. 2012. A review of fire effects on bats and bat habitat in the Eastern oak region. Pages 170-191 in: D.C. Dey, M.C. Stambaugh, S.L. Clark, and C.J. Schweitzer, editors. Proceedings of the 4th Fire in Eastern Oak Forests Conference. USDA Forest Service General Technical Report NRS-P-102, Northern Research Station, Newtown Square, Pennsylvania, 
USA.

Peters, D.C., J.M. Brooke, E.P. Tanner, A.M. Unger, P.D. Keyser, C.A. Harper, J.D. Clark, and J.J. Morgan. 2015. Impact of experimental habitat manipulation of northern bobwhite survival. Journal of Wildlife Management 79: 605-617. doi: 10.1002/jwmg.873

Peterson, D.W., and P.B. Reich. 2001. Prescribed fire in oak savanna: fire frequency effects on stand structure and dynamics. Ecological Applications 11: 914-927. doi: 10.1890/1051-0761(2001)011[0914:PFIOSF]2.0.CO;2

Peterson, S.M., and P.B. Drewa. 2006. Did lightning-initiated growing season fires characterize oak-dominated ecosystems of southern Ohio? Journal of the Torrey Botanical Society 133: 217-224. doi: 10.3159/1095-5674(2006)133[217:DLGSFC]2.0.CO;2

Pickens, B.A., and K.V. Root. 2008. Factors affecting host-plant quality and nectar use for the Karner blue butterfly: implications for oak savanna restoration. Natural Areas Journal 28: 210-217. doi: 10.3375/0885-8608(2008)28[210:FAHQAN]2.0.CO;2

Raybuck, A.L., C.E. Moorman, S.R. Fritts, C.H. Greenberg, C.S. DePerno, D.M. Simon, and G.S. Warburton. 2015. Do silvicultural practices to restore oaks affect salamanders in the short term? Wildlife Biology 21: 186-194. doi: 10.2981/wlb.00076

Renken, R.B. 2006. Does fire affect amphibians and reptiles in eastern US oak forests? Pages 158-166 in: M.B. Dickinson, editor. Fire in Eastern oak forests: delivering science to land managers. USDA Forest Service General Technical Report NRS-P-1, Northern Research Station, Newtown Square, Pennsylvania, USA.

Robertson, K.M., and T.L. Hmielowski. 2014. Effects of fire frequency and season on resprouting of woody plants in southeastern US pine-grassland communities. Oecologia 174: 765776. doi: 10.1007/s00442-013-2823-4

Rodrigue, J.L., T.M. Schuler, and M.A. Menzel. 2001. Observations of bat activity during prescribed burning in West Virginia. Bat Research News 42: 48-49.

Roseberry, J.L., and W.D. Klimstra. 1984. Population ecology of the bobwhite. Southern Illinois University, Carbondale, Illinois, USA.

Rowan, E.L., W.M. Ford, S.B. Castleberry, J.L. Rodrigue, and T.M. Schuler. 2005. Response of Eastern chipmunks to single application spring prescribed fires on the Fernow Experimental Forest. USDA Forest Service Research Paper NE-727, Northern Research Station, Newtown Square, Pennsylvania, USA.

Royo, A.A., R. Collins, M.B. Adams, C. Kirschbaum, and W.P. Carson. 2010. Pervasive interactions between ungulate browsers and disturbance regimes promote temperate forest herbaceous diversity. Ecology 91: 93-105. doi: 10.1890/08-1680.1

Ruffner, C.M., and M.D. Abrams. 1998. Lightning strikes and resultant fires from archival (1912-1917) and current (1960-1997) information in Pennsylvania. Journal of the Torrey Botanical Society 125: 249-252. doi: 10.2307/2997223

Rush, S., N. Klaus, T. Keyes, J. Petrick, and R. Cooper. 2012. Fire severity has mixed benefits to breeding bird species in the southern Appalachians. Forest Ecology and Management 263: 94-100. doi: 10.1016/j.foreco.2011.09.005

Russell, K.R., D.H. Van Lear, and D.C. Guynn. 1999. Prescribed fire effects on herpetofauna: review and management implications. Wildlife Society Bulletin 27: 374-384.

Sandeno, C. 2015. Northern long-eared bat: for land and resource management plans of the US Forest Service Eastern Region. USDA Forest Service Final Report, Region 9, Milwaukee, Wisconsin, USA.

Saugey, D.A., R.L. Vaughn, B.G. Curmp, and G.A. Heidt. 1998. Notes on the natural history of 
Lasiurus borealis in Arkansas. Journal of the Arkansas Academy of Science 52: 92-98.

Schuler, T.M., M. Thomas-Van Gundy, M.B. Adams, and W.M. Ford. 2010. Seedbank response to prescribed fire in the central Appalachians. USDA Forest Service Research Paper NRS-9, Northern Research Station, Newtown Square, Pennsylvania, USA.

Schuler, T.M., M. Thomas-Van Gundy, M.B. Adams, and W.M. Ford. 2013. Analysis of two pre-shelterwood prescribed fires in a mesic mixed-oak forest in West Virginia. Pages 430446 in: G.W. Miller, T.M. Schuler, K.W. Gottschalk, J.R. Brooks, S.T. Grushecky, B.D. Spong, and J.S. Rentch, editors. Proceedings of the 18th central hardwood forest conference. USDA Forest Service General Technical Report NRS-P-117, Northern Research Station, Newtown Square, Pennsylvania, USA.

Schutz, A.E., W.J. Bond, and M.D. Cramer. 2009. Juggling carbon: allocation patterns of a dominant tree in a fire-prone savanna. Oecologia 160: 235-246. doi: 10.1007/s00442-009-1293-1

Shaw, C.E., C.A. Harper, M.W. Black, and A.E. Houston. 2010. The effects of prescribed burning and understory fertilization on browse production in closed-canopy hardwood stands. Journal of Fish and Wildlife Management 1: 64-72. doi: 10.3996/102009-JFWM-016

Semlitsch, R.D., B.D. Todd, S.M. Blomquist, A.J.K. Calhoun, J.W. Gibbons, J.P. Gibbs, G.J. Graeter, E.B. Harper, D.J. Hocking, M.L. Hunter Jr., D.A. Patrick, T.A.G. Rittenhouse, and B.B. Rothermel. 2009. Effects of timber harvest on amphibian populations: understanding mechanisms from forest experiments. Bioscience 59: 853-862. doi: 10.1525/ bio.2009.59.10.7

Shumway, D., M.D. Abrams, and C.M. Ruffner. 2001. A 400-year history of fire and oak recruitment in an old-growth oak forest in western Maryland, USA. Canadian Journal of Forest Research 31: 1437-1443. doi: 10.1139/x01-079

Silvis, A., W.M. Ford, and E.R. Britzke. 2015a. Day-roost tree selection by northern long-eared bats: what do random tree comparisons and one year of data really tell us? Global Ecology and Conservation 3: 756-763. doi: 10.1016/j.gecco.2015.03.008

Silvis, A., R.E. Thomas, W.M. Ford, E.R. Britzke, and M.J. Friedrich. 2015b. Internal cavity characteristics of northern long-eared bat (Myotis septentrionalis) maternity day-roosts. USDA Forest Service Research Paper NRS-27, Northern Research Station, Newtown Square, Pennsylvania, USA.

Silvis, A., S.D. Gehrt, and R.A. Williams. 2016. Effects of shelterwood harvest and prescribed fire in upland Appalachian hardwood forests on bat activity. Forest Ecology and Management 360: 205-212. doi: 10.1016/j.foreco.2015.10.010

Sisson, D.C., and D.W. Speake. 1994. Spring burning for wild turkey brood habitat: an evaluation. Proceedings of the Annual Conference of the Southeastern Association of Fish and Wildlife Agencies 48: 134-139.

Smith, J.K. 2000. Wildland fire in ecosystems: effects of fire on fauna. USDA Forest Service General Technical Report RMRS-GTR-42-Volume 2, Rocky Mountain Research Station, Fort Collins, Colorado, USA.

Sparks, J.C., R.E. Masters, D.M. Engle, M.W. Palmer, and G.A. Bukenhofer. 1998. Effects of late growing-season and late dormant-season prescribed fire on herbaceous vegetation in restored pine-grassland communities. Journal of Vegetation Science 9: 133-142. doi: $10.2307 / 3237231$

Sparks, J.C., R.E. Masters, D.M. Engle, M.E. Payton, and G.A. Bukenhofer. 1999. Influence of fire season and fire behavior on woody plants in red-cockaded woodpecker clusters. Wildlife 
Society Bulletin 27: 124-133.

Stambaugh, M., J.M. Varner, R.F. Noss, D.C. Dey, N.L. Christensen, R.F. Baldwin, R.P. Guyette, B.B. Hanberry, C.A. Harper, S.G. Lindblom, and T.A. Waldrop. 2015. Clarifying the role of fire in the deciduous forests of eastern North America: reply to Matlack. Conservation Biology 29: 942-946. doi: 10.1111/cobi.12473

Starbuck, C.A., S.K. Amelon, and F.R. Thompson III. 2015. Relationships between bat occupancy and habitat and landscape structure along a savanna, woodland, forest gradient in the Missouri Ozarks. Wildlife Society Bulletin 39: 20-30. doi: 10.1002/wsb.512

Stribling, H.L., and M.G. Barron. 1995. Short-term effects of cool and hot prescribed burning on breeding songbird populations in the Alabama Piedmont. Southern Journal of Applied Forestry 19: 18-22.

Swift, L.W., K.J. Elliot, R.D. Ottmar, and R.E. Vihnanek. 1993. Site preparation burning to improve southern Appalachian pine-hardwood stands: fire characteristics and soil erosion, moisture, and temperature. Canadian Journal of Forest Research 23: 2242-2254. doi: 10.1139/ x93-278

Thatcher, B.S., D.G. Krementz, and M.S. Woodrey. 2006. Henslow's sparrow winter-survival estimates and response to prescribed burning. Journal of Wildlife Management 70: 198-206. doi: 10.2193/0022-541X(2006)70[198:HSWEAR]2.0.CO;2

Thomas-Van Gundy, M.A., G.J. Nowacki, and T.M. Schuler. 2007. Rule-based mapping of fire-adapted vegetation and fire regimes for the Monongahela National Forest. USDA Forest Service Research Paper NRS-12, Northern Research Station, Newtown Square, Pennsylvania, USA.

Towne, E.G., and J.M. Craine. 2013. Ecological consequences of shifting the timing of burning tallgrass prairie. PLoS ONE 9: e103423. doi: 10.1371/journal.pone.0103423

Tucker, J.W., W.D. Robinson, and J.B. Grand. 2004. Influence of fire on Bachman's sparrow, an endemic North American songbird. Journal of Wildlife Management 68: 1114-1123. doi: 10.2193/0022-541X(2004)068[1114:IOFOBS]2.0.CO;2

Unger, A.M., E.P. Tanner, C.A. Harper, P.D. Keyser, F.T. van Manen, J.J. Morgan, and D.L. Baxley. 2015. northern bobwhite habitat selection on a reclaimed surface coal mine in Kentucky. Journal of the Southeastern Association of Fish and Wildlife Agencies 2: 235-246.

USDA Forest Service. 2015. Collaborative Forest Landscape Restoration Program 5-Year Report. Report FS-1047. <http://www.fs.fed.us/restoration/documents/cflrp/CFLRP_5-YearReport.pdf $>$. Accessed 10 November 2015.

Van Lear, D.H., and T.A. Waldrop. 1989. History, uses, and effects of fire in the Appalachians. USDA Forest Service General Technical Report SE-54, Southern Research Station, Asheville, North Carolina, USA.

Van Lear, D.H., W.D. Carroll, P.R. Kapeluck, and R. Johnson. 2005. History and restoration of the longleaf pine-grassland ecosystem: implications for species at risk. Forest Ecology and Management 211: 150-165. doi: 10.1016/j.foreco.2005.02.014

van Manen, F.T., and M.R. Pelton. 1997. A GIS model to predict black bear habitat use. Journal of Forestry 95: 6-12.

Varner, J.M., J.M. Kane, J.K. Kreye, and E. Engber. 2015. The flammability of forest and woodland litter: a synthesis. Current Forestry Reports 1: 91-99. doi: 10.1007/s40725-015-0012-X

Wade, D.D., B.L. Brock, P. Brose, J.B. Grace, G.A. Hoch, W.A. Patterson. 2000. Fire in Eastern ecosystems. Pages 53-96 in: J.K. Brown and J.K. Smith, editors. Wildland fire in ecosystems: effects of fire on flora. USDA Forest Service General Technical Report RMRS-GTR- 
42-Volume 2, Rocky Mountain Research Station. Fort Collins, Colorado, USA.

Waldrop, T.A., D.L. White, and S.M. Jones. 1992. Fire regimes for pine-grassland communities in the southeastern United States. Forest Ecology and Management 47: 195-210. doi: 10.1016/0378-1127(92)90274-D

Walters, J.R. 1997. Population and management of red-cockaded woodpecker on Croatan National Forest, 1988-1997. USDA Forest Service Project Final Report, Southern Research Station, Asheville, North Carolina, USA.

Wendel, G.W., and H.C. Smith. 1988. Effects of a prescribed fire in a central Appalachian oak-hickory stand. USDA Forest Service Research Paper NE-594, Northern Research Station, Broomall, Pennsylvania, USA.

Wenger, K.F. 1953. The sprouting of sweetgum in relation to season of cutting and carbohydrate content. Plant Physiology 28: 35-49. doi: 10.1104/pp.28.1.35

Whitaker, D.M., Stauffer D.F., G.W. Norman, P.T. Devers, T.J. Allen, S. Bittner, D.A. Buehler, J. Edwards, S. Friedhoff, W.M. Giuliano, C.A. Harper, and B. Tefft. 2006. Factors affecting habitat use by Appalachian ruffed grouse. Journal of Wildlife Management 70: 460-471. doi: 10.2193/0022-541X(2006)70[460:FAHUBA]2.0.CO;2

Wilson, C.W., R.E. Masters, and G.A. Bukenhofer. 1995. Breeding bird response to pine-grassland community restoration for red-cockaded woodpeckers. Journal of Wildlife Management 59: 56-67. doi: 10.2307/3809116

Wright, H.A., and A.W. Bailey. 1982. Fire ecology: United States and southern Canada. John Wiley and Sons, New York, New York, USA.

Womack, K.M., S.K. Amelon, and F.R. Thompson III. 2013. Resource selection by Indiana bats during the maternity season. Journal of Wildlife Management 77: 707-715. doi: 10.1002/ jwmg.498

Wunz, G.A., and J.C. Pack. 1992. Eastern turkey in Eastern oak-hickory and Northern hardwood forests. Pages 232-264 in: J.G. Dickson, editor. The wild turkey: biology and management. Stackpole Books, Harrisburg, Pennsylvania, USA.

Yaussy, D.A., compiler. 2000. Proceedings of a workshop on fire, people, and the central hardwoods landscape. USDA Forest Service General Technical Report NE-274, Northern Research Station, Newtown Square, Pennsylvania, USA. 
Appendix 1. Recommendations and considerations when burning for various wildlife species or taxonomic groups in the Central Hardwoods and Appalachian Forest regions.

\begin{tabular}{|c|c|c|c|}
\hline $\begin{array}{l}\text { Species or } \\
\text { taxonomic } \\
\text { group }\end{array}$ & Recommended fire prescription & Considerations or concerns & $\begin{array}{c}\text { Key citations related to } \\
\text { habitat requirements and } \\
\text { wildlife response }\end{array}$ \\
\hline $\begin{array}{l}\text { Understory- } \\
\text { nesting } \\
\text { songbirds }\end{array}$ & $\begin{array}{l}\text { Low-intensity fire on } 5 \mathrm{yr} \text { to } \\
7 \mathrm{yr} \text { return interval in mature } \\
\text { hardwoods }\end{array}$ & $\begin{array}{l}\text { Avoid burning large, contiguous } \\
\text { areas during nesting from April } \\
\text { through July }\end{array}$ & $\begin{array}{l}\text { Stribling and Barron 1995; } \\
\text { Greenberg et al. } 2007 ; \\
\text { McCord et al. } 2014\end{array}$ \\
\hline $\begin{array}{l}\text { Open-canopy } \\
\text { songbirds }\end{array}$ & $\begin{array}{l}\text { Low- to moderate-intensity } \\
\text { fire within a } 6 \text { yr to } 7 \text { yr return } \\
\text { interval to maintain habitat in } \\
\text { existing woodlands }\end{array}$ & $\begin{array}{l}\text { Moderate- to high-intensity fire } \\
\text { required to develop habitat where } \\
\text { closed canopy conditions exist } \\
\text { and silvicultural treatment is not } \\
\text { implemented }\end{array}$ & $\begin{array}{l}\text { Wilson et al. 1995; Blake 2004; } \\
\text { Bakermans et al. 2012; } \\
\text { Barrioz et al. } 2013\end{array}$ \\
\hline $\begin{array}{l}\text { Shrubland } \\
\text { songbirds }\end{array}$ & $\begin{array}{l}\text { Late dormant-season fire on a } 3 \\
\text { yr to } 5 \text { yr return interval in areas } \\
\text { with considerable shrub cover }\end{array}$ & $\begin{array}{l}\text { Avoid burning large, contiguous } \\
\text { areas during nesting from April } \\
\text { through July; burning just prior } \\
\text { to green-up maintains cover for } \\
\text { wintering sparrows }\end{array}$ & $\begin{array}{l}\text { Wilson et al. 1995; } \\
\text { Hunter et al. 2001; } \\
\text { Thatcher } \text { et al. } 2006\end{array}$ \\
\hline $\begin{array}{l}\text { Grassland } \\
\text { songbirds }\end{array}$ & $\begin{array}{l}\text { Dormant- or late growing-season } \\
\text { fire on a } 1 \text { yr to } 3 \text { yr return } \\
\text { interval in grasslands that meet } \\
\text { area constraints of grassland } \\
\text { birds }\end{array}$ & $\begin{array}{l}\text { Avoid burning large, contiguous } \\
\text { areas during nesting from April } \\
\text { through July; burning just prior } \\
\text { to green-up maintains cover } \\
\text { for wintering sparrows; late } \\
\text { growing-season fire may help } \\
\text { reduce woody encroachment }\end{array}$ & $\begin{array}{l}\text { Hovick et al. 2015; } \\
\text { Giocomo et al. } 2008\end{array}$ \\
\hline $\begin{array}{l}\text { Northern } \\
\text { bobwhite }\end{array}$ & $\begin{array}{l}\text { Late dormant-season or early } \\
\text { growing-season fire on a } 2 \text { yr } \\
\text { to } 4 \text { yr return interval in early } \\
\text { successional communities and } \\
\text { oak-pine savannas }\end{array}$ & $\begin{array}{l}\text { Most nesting occurs after April; } \\
\text { maintaining shrub cover in close } \\
\text { proximity in a relatively open } \\
\text { landscape is critical }\end{array}$ & $\begin{array}{l}\text { Roseberry and Klimstra 1984; } \\
\text { Brooke et al. } 2015\end{array}$ \\
\hline Wild turkey & $\begin{array}{l}\text { Low- to moderate-intensity fire } \\
\text { on a } 3 \text { yr to } 5 \text { yr return interval }\end{array}$ & $\begin{array}{l}\text { Avoid burning large, contiguous } \\
\text { units during nesting and brood- } \\
\text { rearing (April to June) }\end{array}$ & McCord et al. 2014 \\
\hline Ruffed grouse & $\begin{array}{l}\text { Low-intensity dormant-season } \\
\text { fire on a } 6 \text { yr to } 8 \text { yr return } \\
\text { interval in mature oak-hickory; } \\
\text { moderate-intensity dormant- } \\
\text { season fire on } 15 \text { yr to } 20 \text { yr } \\
\text { return interval in young forest } \\
\text { stands }\end{array}$ & $\begin{array}{l}\text { Avoid burning large, contiguous } \\
\text { units during nesting and brood- } \\
\text { rearing (April through June) }\end{array}$ & $\begin{array}{l}\text { Jones and Harper 2007; } \\
\text { Jones et al. } 2008\end{array}$ \\
\hline $\begin{array}{l}\text { White-tailed } \\
\text { deer }\end{array}$ & $\begin{array}{l}\text { Low- to moderate intensity } \\
\text { dormant- or late growing-season } \\
\text { fire on 3- to 5-yr return interval }\end{array}$ & $\begin{array}{l}\text { Avoid burning during fawning } \\
\text { season (May to June); fire effects } \\
\text { will be minimal under closed } \\
\text { canopy conditions unless fire } \\
\text { intensity is great enough to kill } \\
\text { some trees and allow light into } \\
\text { the stand }\end{array}$ & Lashley et al. 2011 \\
\hline Bats & $\begin{array}{l}\text { Low-intensity dormant- or late } \\
\text { growing-season fire on } 5 \text { yr to } 7 \\
\text { yr return interval }\end{array}$ & $\begin{array}{l}\text { Higher-intensity fires may create } \\
\text { snags used as roosting sites; } \\
\text { lower-intensity fires reduce } \\
\text { clutter for foraging bats }\end{array}$ & $\begin{array}{l}\text { Boyles and Aubrey 2006; } \\
\text { Johnson et al. 2009; } \\
\text { Johnson et al. 2010; Perry 2012; } \\
\text { Ford et al. 2015; } \\
\text { Silvis et al. } 2016\end{array}$ \\
\hline Reptiles & $\begin{array}{l}\text { Dormant-season fire in early } \\
\text { successional communities, } \\
\text { savannas, and woodlands }\end{array}$ & $\begin{array}{l}\text { Avoid early growing-season } \\
\text { burning near known snake } \\
\text { hibernacula when snakes are } \\
\text { emerging }\end{array}$ & $\begin{array}{l}\text { Moseley et al. 2003; } \\
\text { Keyser et al. 2004; } \\
\text { Greenberg and Waldrop 2008; } \\
\text { Matthews et al. } 2010\end{array}$ \\
\hline Amphibians & Dormant-season fire & $\begin{array}{l}\text { Canopy reduction from fire- } \\
\text { induced tree mortality and leaf- } \\
\text { litter removal reduces habitat } \\
\text { quality for salamanders for } \\
\text { at least } 1 \text { yr post fire; canopy } \\
\text { reduction at woodland vernal } \\
\text { pools increases Anuran diversity }\end{array}$ & $\begin{array}{l}\text { Renken 2006; Ford et al. 2010; } \\
\text { Matthews et al. } 2010 \text {; } \\
\text { O’Donnell et al. } 2015\end{array}$ \\
\hline
\end{tabular}


Appendix 2. Periods of the year when burning could be problematic for various species and species groups in the Central Hardwoods and Appalachians ${ }^{1}$.

\begin{tabular}{|c|c|c|c|c|c|c|c|c|c|c|c|c|}
\hline Species or taxonomic group & Jan & Feb & Mar & Apr & May & Jun & Jul & Aug & Sep & Oct & Nov & Dec \\
\hline $\begin{array}{l}\text { White-tailed deer } \\
\text { (primary fawning season) }\end{array}$ & & & & & $\mathrm{X}$ & $\mathrm{X}$ & & & & & & \\
\hline $\begin{array}{l}\text { Eastern cottontail } \\
\text { (primary nesting in early } \\
\text { successional areas) }\end{array}$ & & & $X$ & $\mathrm{X}$ & & & & & & & & \\
\hline $\begin{array}{l}\text { Bats } \\
\text { (maternal colonies in } \\
\text { woodlands and forests) }\end{array}$ & & & & & $\mathrm{X}$ & $\mathrm{X}$ & $\mathrm{X}$ & $\mathrm{X}$ & & & & \\
\hline $\begin{array}{l}\text { Wild turkey } \\
\text { (nesting and brooding) }\end{array}$ & & & & $\mathrm{X}$ & $\mathrm{X}$ & $\mathrm{X}$ & & & & & & \\
\hline $\begin{array}{l}\text { Northern bobwhite } \\
\text { (primary nesting in early } \\
\text { successional areas) }\end{array}$ & & & & & & $\mathrm{X}$ & $\mathrm{X}$ & $\mathrm{X}$ & & & & \\
\hline $\begin{array}{l}\text { Ruffed grouse } \\
\text { (nesting and brooding in } \\
\text { forests) }\end{array}$ & & & & $\mathrm{X}$ & $\mathrm{X}$ & $\mathrm{X}$ & & & & & & \\
\hline $\begin{array}{l}\text { Forest songbirds associated } \\
\text { with understory } \\
\text { (nesting) }\end{array}$ & & & & & $\mathrm{X}$ & $\mathrm{X}$ & & & & & & \\
\hline $\begin{array}{l}\text { Grassland songbirds } \\
\text { (nesting) }\end{array}$ & & & & & $\mathrm{X}$ & $\mathrm{X}$ & & & & & & \\
\hline $\begin{array}{l}\text { Shrubland songbirds } \\
\text { (nesting) }\end{array}$ & & & & & $X$ & $\mathrm{X}$ & & & & & & \\
\hline $\begin{array}{l}\text { Reptiles } \\
\text { (clustered at hibernacula) }\end{array}$ & & & & $\mathrm{X}$ & & & & & & $\mathrm{X}$ & & \\
\hline $\begin{array}{l}\text { Woodland salamanders } \\
\text { (most active aboveground) }\end{array}$ & & & & & $\mathrm{X}$ & $\mathrm{X}$ & $\mathrm{X}$ & & & & & \\
\hline
\end{tabular}

${ }^{1}$ This table is not meant to imply that burning should not be conducted at particular times of the year, but to illustrate periods in the year when various species and species guilds are most vulnerable to fire. Burning relatively small areas and on relatively long intervals during any time of year should not have population-level effects. However, land managers with a particular interest in various species or species groups may use this information to help ensure that they are burning during times of the year that are least likely to adversely affect those species. 